Article

\title{
Portfolios of Climate Smart Agriculture Practices in Smallholder Rice-Wheat System of Eastern Indo-Gangetic Plains-Crop Productivity, Resource Use Efficiency and Environmental Foot Prints
}

\author{
Deepak Bijarniya ${ }^{1}$, C. M. Parihar ${ }^{2}$, R. K. Jat ${ }^{3}$, Kailash Kalvania ${ }^{1}$, S. K. Kakraliya ${ }^{4}$ \\ and M. L. Jat $1, * \mathbb{D}$ \\ 1 International Maize and Wheat Improvement Center (CIMMYT)-India, New Delhi 110 012, India; \\ d.bijarniya@cgiar.org (D.B.); k.kalvania@cgiar.org (K.K.) \\ 2 ICAR-Indian Agricultural Research Institute (IARI), New Delhi 110 012, India; pariharcm@gmail.com \\ 3 Borlaug Institute of South Asia (BISA), CIMMYT, Pusa, Samastipur, Bihar 848125, India; r.jat@cgiar.org \\ 4 ICAR-Central Soil Salinity Research Institute, Karnal 132001, India; kakraliyask@gmail.com \\ * Correspondence: m.jat@cgiar.org; Tel.: +91-9999108787
}

Received: 27 August 2020; Accepted: 17 September 2020; Published: 14 October 2020

Abstract: The conventional tillage based rice-wheat system (RWS) in Indo-genetic plains (IGP) of South Asia is facing diverse challenges like increase in production cost and erratic climatic events. This results in stagnated crop productivity and declined farm profitability with increased emission of greenhouse gases. Therefore, 3-year multi-location farmer's participatory research trial was conducted to assess the impact of crop establishment and residue management techniques on crop productivity, economic profitability and environmental footprints in RWS. The aim of this study was to analyze the effect of combinations of improved agronomic technologies compared to farmer's practices (FP) on crop productivity, profitability, resource use efficiency and environmental footprints. The experiment had six scenarios that is, S1-Farmer's practice; Conventional tillage (CT) without residue; S2-CT with residue, S3- Reduced tillage (RT) with residue + Recommended dose of fertilizer (RDF); S4-RT/zero tillage $(\mathrm{ZT})$ with residue $+\mathrm{RDF}$, S5-ZT with residue $+\mathrm{RDF}+$ green seeker + tensiometer + information \& communication technology + crop insurance and S6- S5 + site specific nutrient management. Climate smart agriculture practices (CSAPs; mean of S4, S5 and S6) increase system productivity and farm profitability by $10.5 \%$ and $29.4 \%$ (on 3 yrs' mean basis), whereas, improved farmers practices (mean of S2 and S3) resulted in only 3.2\% and 5.3\% increments compared to farmer's practice (S1), respectively. On an average, CSAPs saved 39.3\% of irrigation water and enhanced the irrigation and total water productivity by $53.9 \%$ and $18.4 \%$ than FP, respectively. In all the 3-years, CSAPs with high adaptive measures enhanced the energy-use-efficiency (EUE) and energy productivity (EP) by $43 \%-54 \%$ and $44 \%-61 \%$, respectively than FP. In our study, global warming potential (GWP), GHG emission due to consumption energy and greenhouse gas intensity were recorded lower by $43 \%, 56 \%$ and $59 \%$ in Climate Smart Agriculture (CSA) with high adaptive measures than farmers practices (3652.7 $\mathrm{kg} \mathrm{CO}_{2}$ eq. ha ${ }^{-1} \mathrm{yr}^{-1}, 722.2 \mathrm{~kg} \mathrm{CO}_{2}$ eq. $\mathrm{ha}^{-1} \mathrm{yr}^{-1}$ and $718.7 \mathrm{Mg} \mathrm{kg}^{-1} \mathrm{CO}_{2}$ eq. ha ${ }^{-1} \mathrm{yr}^{-1}$ ). The findings of the present study revealed that CSA with adaption of innovative measures (S6) improved 3-year mean system productivity by $10.5 \%$, profitability by $29.4 \%$, water productivity and energy productivity by $18.3 \%$ and $48.9 \%$, respectively than FP. Thus, the results of our 3-year farmer's participatory study suggest that in a RW system, climate smart agriculture practices have better adaptive capacity and could be a feasible option for attaining higher yields, farm profitability, energy-use efficiency and water productivity with sustained/improved environmental quality in smallholder production systems of Eastern IGP of India and other similar agro-ecologies of South Asia. Finally, the adoption of these CSAPs should be promoted in the RW rotation of IGP to ensure food security, restoration of soil health and to mitigate climate change, the key sustainable development goals (SDGs). 
Keywords: conservation agriculture; global warming potential; energy use efficiency; water productivity

\section{Introduction}

Agriculture is a significant contributor to the economy of developing nations like India, Bangladesh, Nepal and Pakistan. This region of Indo-genetic plains (IGP) covers about 44 million hectares'(Mha) land area, out of which, Rice wheat cropping system (RWCS) alone occupies about 13.5 Mha area [1]. In India, RWCS covers a $~ 10.5$ Mha area and contributes $\sim 40 \%$ of the country's total food grain basket and is fundamental for employment and income generation and for livelihood security for millions of people [2,3]. Most of the productivity gains of RWCS during the green revolution era (1960s) was realized in western IGP due to adoption of high yielding varieties and improved crop management practices but the eastern IGP still lagging behind. The Eastern IGP is characterized as a higher population density, small and fragmented land pieces, poor agricultural input and output marketing infrastructure, less access to newly developed advances and better crop production technologies and repeated weather aberrations (floods, droughts and heat stress). Further, the use of traditional crop management practices like conventional wet tillage in rice in cereal-based cropping systems not only entail higher production costs but also leads to depletion and/or degradation of natural resources (water, soil, biodiversity), less input-use efficiency and higher environmental footprints $[4,5]$. Moreover, the conventional rice planting method also leads to delay sowing of following wheat crop [6]. These frequent wet tillage operations in rice are not only labor, water, time, energy and carbon inefficient but also deteriorate the soil health and results in a lower yield of succeeding wheat crop by $8-9 \%$ compared to the sowing of wheat subsequent to dry direct seeding of rice [7]. Further, the traditional wheat planting involves repetitive dry tillage to prepare the field followed by the broadcasting of wheat seeds which also leads to further delay in wheat seeding by almost a week compared to zero tillage planting [6]. These above mentioned factors stagnant the productivity growth of RWCS in the Eastern IGP [8]. There is limited scope for spatial expansion of crop production area to increase food production for ever increasing human population [9].

In South Asia and elsewhere, recent field validation reports from different studies have revealed that the climate smart agricultural practices (CSAPs) have the coping mechanisms for emerging climate change issues [10]. The components of CSAPs are building adaptive capacity in terms of improving crop productivity, resource-use efficiency, farm profitability and carbon sequestration with reduced climate change vulnerability and greenhouse gas emissions [11]. The CSAPs such as the use of high-yielding and stress-tolerant varieties/genotypes, adoption of superior crop management technologies such as water management technologies like direct seeded rice (DSR), laser-assisted land levelling, precision nutrient management (e.g., 4R stewardship based nutrient expert tools, sensor-based $\mathrm{N}$ application-green seeker, etc.), carbon management through residue retention/incorporation, weather forecast technologies, crop insurance, energy saving technologies like zero tillage and ICTs (Information and communication technologies) can increase the crop productivity and farm profitability even under adverse crop production situations $[12,13]$. The adoption of climate smart agriculture practices addresses the number of constraints that is, moisture stress, declining low soil fertility and groundwater table, terminal heat stress, greenhouse gas (GHGs) emissions and lower crop yields [14,15]. The past, several studies have been conducted on individual /specific crop management practice such as tillage or nutrients or water or residue management or weather forecasting or crop insurance and so forth. On the basis of findings of these individual technology based studies, a number of resource use efficient technologies have been identified, developed and deployed to address the recent challenges related to natural resource degradation and climatic risks management in the RW (rice-wheat) system of Eastern IGP. However, these crop management practices individually or in isolation may or may not able to play their potential role in adapting the climatic risks and reducing GHG emissions. Therefore, layering 
of these practices and services in optimal combinations may help in adapting to climate risks and building resilience to extreme weather and climate variability, under diverse production systems and ecologies to ensure future food security.

Moreover, the erratic challenges in RW system of small farm dominated typology of Eastern IGP cannot be tended to with ware of commodity-based approach and need a framework based holistic management strategy. Although a few studies have quantified crop yield and soil health but; simultaneous study on crop productivity, farm profitability, resource use efficiency and emission of GHGs under different crop management practices is lacking. Therefore, systematic research on CSAPs is required to assess the potential benefits in the RWCS of the small farm holding dominated typology of Eastern IGP. Against this background, we conducted participatory strategic research trials with different portfolios of climate smart agricultural practices under six scenarios. Based on the 3-years findings of these participatory trials in this paper, we analyze and present the impact of climate smart agricultural practices on crop productivity, farm profitability, water and energy use efficiency and GHGs emissions. The main objective of this study was-to assess the effect of different climate smart agricultural practices on crop productivity, farm profitability, water and energy use efficiency and GHGs emissions in the RW system. We hypothesized that in medium-term ( $\leq 5$-years study), CSA practices would increase crop productivity, profitability, water and energy use efficiency with lower GHGs emissions as compared to conventional tillage practices in the RW system.

\section{Material and Methods}

\subsection{Experimental Site and Weather Condition}

During 2014-2015, 2015-2016 and 2016-2017, a farmer participatory research trial was conducted in three climate smart villages (CSVs), piloted by the CGIAR (Consultative group on International Agricultural Research) research program on climate change agriculture and food security (CCAFS). The experiment was conducted in the Eastern IGP, Sindwari $\left(25^{\circ} 44^{\prime} \mathrm{N} 085^{\circ} 16^{\prime}\right.$ E), Kanahauli dhanraj $\left(25^{\circ} 47^{\prime} \mathrm{N} 085^{\circ} 21^{\prime} \mathrm{E}\right.$ and Panapur $\left(25^{\circ} 46^{\prime} \mathrm{N} 085^{\circ} 21^{\prime} \mathrm{E}\right)$ in the Vashali district of Bihar, India and each location was considered a replication. The climate of the sites is characterized by hot and humid summer and cold winters with $1140 \mathrm{~mm}$ average annual rainfall, 70 per cent of which received between June to September months. The mean annual maximum and minimum temperature is 30 and $19{ }^{\circ} \mathrm{C}$, respectively with $60-95 \%$ relative humidity throughout the year. Each scenario was replicated thrice in production scale plots $\left(>1000 \mathrm{~m}^{2}\right)$ in a randomized complete block design and repeated in three locations (Figure 1).

\subsection{Experimental Details and Design}

The trial was started in the rainy season of 2014 with six scenarios of nine different combinations of crop management interventions over existing farmer's practices. In these six scenarios, we have focused on crop productivity, farm profitability, water and energy use efficiency and climate change risks. In scenario 1(S1) the existing farmer's practices were adopted, while in scenario 2 (S2) and 3 (S3) combination of improved practices of tillage, crop establishment, residue and nutrient management were adopted as improved farmer's practices. Scenario 4, 5 and 6 (S4, S5 and S6) were designed based on the available range of climate smart agriculture practices (tillage, crop establishment, laser land levelling, residue, water and nutrient management, information and communication technology (ICT) and crop insurance). Using Information and Communication Technology's (ICTs) in innovative ways through ICT-enabled services (cellphones) helps in disseminating timely information agricultural advisories, financial services, agricultural marketing and risk transfer to the farmer to improve their capacity and mitigate risks. (detail the description is given in Tables 1 and 2). To find out the current farmers practices in RW rotation in the region, a 50 farm families were surveyed from nearby villages of experimental sites. Puddled transplanted rice and broadcasting of wheat after intensive tillage 
operation is the common practices among the study area farmers. Under the different scenarios, the various protocols of crop management practices were adopted and are presented in Tables 1 and 2.

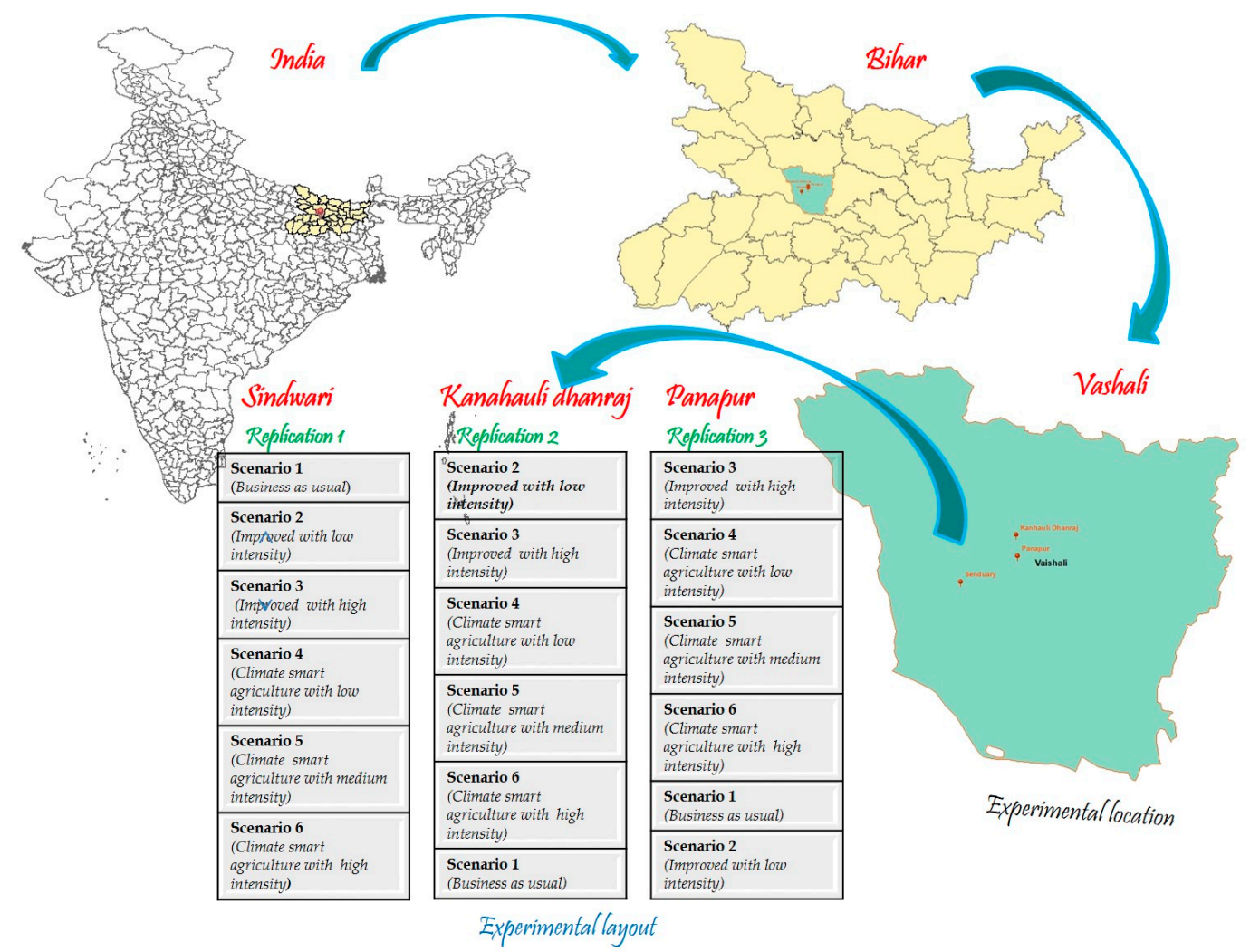

Figure 1. Location and layout of experimentation; Sindwari $\left(25^{\circ} 44^{\prime} \mathrm{N} 085^{\circ} 16^{\prime} \mathrm{E}\right)$, Kanahauli dhanraj $\left(25^{\circ} 47^{\prime} \mathrm{N} 085^{\circ} 21^{\prime} \mathrm{E}\right.$ and Panapur $\left(25^{\circ} 46^{\prime} \mathrm{N} 085^{\circ} 21^{\prime} \mathrm{E}\right)$ in Vashali district of Bihar, India.

\subsection{Soil Sampling and Analysis}

Initial soil samples were taken from the three depths $(0-5,5-15,15-30 \mathrm{~cm})$ prior to the start of the experiment using a spiral auger. A composite soil sample for each depth was collected from four spots within an experimental plot. Within each grid cell, the soil was collected from four spots and composited for each depth. The method proposed by Reference [16] was used for the measurement of Bulk Density (BD) by using pistons auger and the textural class was determined by the United States Department of Agriculture (USDA) system. Soil pH and electrical conductivity (EC) was determined by Reference [17] method having the saturation extract of 1: 2 (soil: water suspension) solution. The rapid titration method of Reference [18] was used to analyze soil organic carbon. The soil available $\mathrm{N}$ was determined by alkaline permanganate method [19], extractable P by $0.5 \mathrm{M} \mathrm{NaHCO}_{3}$ [20] method and $1 \mathrm{~N} \mathrm{NH}_{4} \mathrm{OAC}$ extractable $\mathrm{K}$ by flame photometer method [21]. The experimental soil was clay loam in texture and low in nitrogen and medium in available phosphorus and potassium. 
Table 1. Notations and description of management protocols adopted under different scenarios in rice-wheat system.

\begin{tabular}{|c|c|c|c|c|c|c|c|c|c|c|}
\hline \multicolumn{2}{|c|}{ Scenarios Details } & \multirow{2}{*}{$\begin{array}{c}\text { Tillage } \\
\text { CT }\end{array}$} & \multirow{2}{*}{$\begin{array}{c}\text { Crop Establishment } \\
\text { TPR with random geometry in } \\
\text { rice and CTW using seed } \\
\text { broadcasting }\end{array}$} & \multirow{2}{*}{$\begin{array}{c}\begin{array}{c}\text { Laser Land } \\
\text { Levelling }\end{array} \\
\text { No }\end{array}$} & \multirow{2}{*}{$\begin{array}{l}\text { Cultivars } \\
\text { Rajshree; } \\
\text { PBW343 }\end{array}$} & \multirow{2}{*}{$\begin{array}{c}\begin{array}{c}\text { Residue } \\
\text { Management }\end{array} \\
\begin{array}{c}\text { FP, Residue } \\
\text { removed }\end{array}\end{array}$} & \multirow{2}{*}{$\begin{array}{c}\begin{array}{c}\text { Water } \\
\text { Management }\end{array} \\
\text { FP }\end{array}$} & \multirow{2}{*}{$\begin{array}{c}\begin{array}{c}\text { Nutrient } \\
\text { Management }\end{array} \\
\text { FFP }\end{array}$} & \multirow{2}{*}{$\begin{array}{c}\text { ICT } \\
\text { None }\end{array}$} & \multirow{2}{*}{$\begin{array}{c}\begin{array}{c}\text { Crop } \\
\text { Insurance }\end{array} \\
\text { None }\end{array}$} \\
\hline S1 & $\begin{array}{l}\text { Farmer } \\
\text { practice }\end{array}$ & & & & & & & & & \\
\hline S2 & $\begin{array}{l}\text { FP with low } \\
\text { intensity of } \\
\text { adaptive } \\
\text { measures }\end{array}$ & CT & $\begin{array}{l}\text { TPR with random geometry in } \\
\text { rice and CTW sown with MCP }\end{array}$ & No & $\begin{array}{l}\text { Rajshree; } \\
\text { PBW343 }\end{array}$ & $\begin{array}{l}50 \% \text { of rice and } \\
25 \% \text { of wheat } \\
\text { residue } \\
\text { incorporated }\end{array}$ & FP & FFP & None & None \\
\hline S3 & $\begin{array}{l}\text { FP with high } \\
\text { intensity of } \\
\text { adaptive } \\
\text { measures }\end{array}$ & RT & $\begin{array}{l}\text { Direct seeding in rice and } \\
\text { wheatsown with MCP }\end{array}$ & No & $\begin{array}{c}\text { Arize } 644 \\
\text { Gold;HD } 2967\end{array}$ & as in IFP & FP & RDF & None & None \\
\hline S4 & $\begin{array}{l}\text { CSA with low } \\
\text { intensity of } \\
\text { adaptive } \\
\text { measures }\end{array}$ & RT-ZT & Same as in S3 & Yes & $\begin{array}{c}\text { Arize } 644 \\
\text { Gold;HD } 2967\end{array}$ & $\begin{array}{l}50 \% \text { of rice and } \\
25 \% \text { of wheat } \\
\text { residue retention }\end{array}$ & SR & RDF & None & None \\
\hline S5 & $\begin{array}{l}\text { CSA with } \\
\text { medium } \\
\text { intensity of } \\
\text { adaptive } \\
\text { measures }\end{array}$ & ZT & Same as in S3 & Yes & $\begin{array}{c}\text { Arize } 644 \\
\text { Gold;HD } 2967\end{array}$ & $\begin{array}{l}50 \% \text { of rice and } \\
25 \% \text { of wheat } \\
\text { residue retention }\end{array}$ & $\begin{array}{l}\text { Tensiometer } \\
\text { based }\end{array}$ & $\begin{array}{l}\text { RDF + GS } \\
\text { guided N }\end{array}$ & Yes & Yes \\
\hline S6 & $\begin{array}{l}\text { CSA with high } \\
\text { intensity of } \\
\text { adaptive } \\
\text { measures }\end{array}$ & ZT & Same as in S3 & Yes & $\begin{array}{c}\text { Arize } 644 \\
\text { Gold;HD } 2967\end{array}$ & Same as in CSA-M & $\begin{array}{l}\text { Tensiometer } \\
\text { based }\end{array}$ & $\begin{array}{l}\mathrm{NE}+\mathrm{GS} \\
\text { guided N }\end{array}$ & Yes & Yes \\
\hline
\end{tabular}

FP: Farmer's practice, CSA: Climate smart agriculture, CT: Conventional tillage, RT: Reduced till, ZT: Zero till, TPR: Transplanted rice, CTW: Conventional till wheat, DSR: Direct seeded rice, MCP: Multi crop planter, RTW: Reduced till wheat, ZTW: Zero till wheat, SR: State recommendation for irrigation, FFP: Farmer's fertilizer practice, RDF: Recommended dose of fertilizer, GS: Green Seeker, NE: Nutrient expert based fertilizer recommendation, ICT: Information and communication technology. 
Table 2. Crop management practices for rice-wheat system under divergent scenarios.

\begin{tabular}{|c|c|c|c|c|c|c|}
\hline $\begin{array}{l}\text { Scenarios } \\
\text { a/Management } \\
\text { Practices }\end{array}$ & $\begin{array}{l}\text { Scenario } 1 \\
\text { (S1) }\end{array}$ & $\begin{array}{l}\text { Scenario } 2 \\
\text { (S2) }\end{array}$ & $\begin{array}{l}\text { Scenario } 3 \\
\text { (S3) }\end{array}$ & $\begin{array}{l}\text { Scenario } 4 \\
\text { (S4) }\end{array}$ & $\begin{array}{l}\text { Scenario } 5 \\
\text { (S5) }\end{array}$ & $\begin{array}{l}\text { Scenario } 6 \\
\text { (S6) }\end{array}$ \\
\hline Field preparation & $\begin{array}{l}\text { Rice- } 2 \text { pass of harrow, } 1 \\
\text { pass of rotavator, } 2 \text { pass } \\
\text { of puddle harrow } \\
\text { followed by (fb) planking; } \\
\text { in wheat- } 2 \text { pass of } \\
\text { harrow and cultivator } \\
\text { each } f b \text { planking }\end{array}$ & Same as in $\mathrm{S} 1$ & $\begin{array}{l}\text { Rice and wheat-1 pass of } \\
\text { harrow, } 1 \text { pass of } \\
\text { cultivator } f b \text { planking; }\end{array}$ & $\begin{array}{l}\text { Rice- Same as in S3; in } \\
\text { wheat zero tillage }\end{array}$ & Zero tillage & Same as in S5 \\
\hline Seed rate $\left(\mathrm{kg} \mathrm{ha}^{-1}\right)^{\mathrm{b}}$ & $12-137$ & Same as in $\mathrm{S} 1$ & $25-100$ & Same as in S3 & Same as in $\mathrm{S} 3$ & Same as in S3 \\
\hline Source of fertilizers & $\begin{array}{c}\text { Di-ammonium phosphate } \\
\text { (DAP) (18:46:0)and } \\
\text { Muriate of potash (MOP) } \\
(0: 0: 60)\end{array}$ & Same as in $\mathrm{S} 1$ & $\begin{array}{l}\text { Urea, DAP, Muriate of } \\
\text { potash (MOP) }(0: 0: 60) \text { and } \\
\text { NPK complex (12:32:16) }\end{array}$ & $\begin{array}{c}\text { Neem coated urea } \\
(46: 0: 0), \text { DAP, MOP and } \\
\text { NPK complex (12:32:16) }\end{array}$ & Same as in S4 & Same as in S4 \\
\hline Dose of Fertilizers & $\begin{array}{c}\text { Rice-134:50:33; Wheat- } \\
\text { 139:50:33; } \mathrm{ZnSO}_{4} @ 25 \mathrm{~kg} \\
\text { ha }^{-1}\end{array}$ & Same as in S1 & $\begin{array}{l}\text { Rice- 150:60:40; } \mathrm{FeSO}_{4} \\
@ 0.5 \% \text {; Wheat- 150:60:40; } \\
\mathrm{ZnSO}_{4} @ 25 \mathrm{~kg} \mathrm{ha}^{-1}\end{array}$ & Same as in S3 & $\begin{array}{c}\text { Rice- 148:60:40 (in 1st yr) } \\
\text { 145:60:40 (in 2nd yr) and } \\
\text { 139:60:40 (in 3rd yr) + FeSO4 } \\
\text { @0.5\% every year; in Wheat- } \\
\text { 144:60:40 (in 1st yr), } \\
\text { 147:60:40 (in 2nd yr) and } \\
\text { 146:60:40 } \\
\text { (in 3rd yr) }\end{array}$ & $\begin{array}{c}\text { Rice- 140:45:58 (in 1st yr), } \\
\text { 132:49:57 (in 2nd yr) and } \\
\text { 130:31:58 (in 3rd yr); + FeSO4 } \\
\text { @0.5\% every year; Wheat- } \\
\text { 132:44:60 (in 1st yr), } 128: 48: 70 \\
\text { (in 2nd yr) and 137:47:65 (in } \\
\text { 3rd yr) }\end{array}$ \\
\hline
\end{tabular}

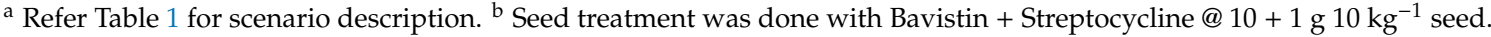




\subsection{Residue Management}

Rice and wheat crops residues were removed or retained according to the treatment/scenarios described in Table 1. In all the scenarios, the crops were harvested manually. The rice crop harvested $30-40 \mathrm{~cm}$ whereas wheat was harvested $10-15 \mathrm{~cm}$ above ground level except for farmer's practices (S1). In S2, before planting of succeeding crop, standing rice and wheat residues were incorporated/mixed during intensive tillage using by harrow and rotavator machines. In S3, standing rice and wheat residues were incorporated during minimum tillage using by harrow machine. In S4, the standing residue of rice was retained at wheat sowing during zero tillage using happy seeder (HS) machine while the standing wheat stubbles ( $15 \mathrm{~cm}$ in height) were incorporated at rice sowing during minimum tillage. In both S5 and S6, standing rice and wheat residues were retained at succeeding crops during zero tillage using HS. In S2, a total of $15.1 \mathrm{t} \mathrm{ha}^{-1}$ of crop residue was incorporated during the study period (2014-2015 to 2016-2017) (Table 3). The total amount of annual residue retained in all five scenarios was ranged from 4.9 to $5.4 \mathrm{t} \mathrm{ha}^{-1} \mathrm{yr}^{-1}$. In S3, a total amount of $1.48 \mathrm{t} \mathrm{ha}^{-1}$ ( $3 \mathrm{yrs}^{\prime}$ mean) wheat residues were mixed and $3.67 \mathrm{tha}^{-1}$ ( $3 \mathrm{yrs}^{\prime}$ mean) of rice residue were retained on the soil surface every year. In S5 and S6, about 5.26 and $5.38 \mathrm{tha}^{-1}$ crop residues were retained annually, respectively (Table 3) and in all the treatments the leftover residues were removed for use as fodder for cattle.

Table 3. Annually added residue inputs from rice and wheat crop grown in rice-wheat system under different crop management scenarios.

\begin{tabular}{|c|c|c|c|c|c|c|c|c|c|}
\hline \multirow[t]{3}{*}{ Scenarios $^{\text {a }}$} & \multicolumn{9}{|c|}{ Residue Incorporated/Retained ( ha $^{-1}$ ) } \\
\hline & \multicolumn{3}{|c|}{ 2014-15 } & \multicolumn{3}{|c|}{$2015-16$} & \multicolumn{3}{|c|}{ 2016-17 } \\
\hline & Rice & Wheat & RW System & Rice & Wheat & RW System & Rice & Wheat & RW System \\
\hline S1 & -NA- & -NA- & -NA- & -NA- & -NA- & -NA- & -NA- & -NA- & -NA- \\
\hline S2 & 3.78 & 1.40 & 5.18 & 3.55 & 1.37 & 4.92 & 3.69 & 1.37 & 5.06 \\
\hline S3 & 3.75 & 1.57 & 5.32 & 3.57 & 1.46 & 5.03 & 3.68 & 1.41 & 5.08 \\
\hline S4 & 3.73 & 1.60 & 5.34 & 3.71 & 1.52 & 5.23 & 3.72 & 1.50 & 5.22 \\
\hline S5 & 3.77 & 1.55 & 5.32 & 3.71 & 1.49 & 5.20 & 3.74 & 1.51 & 5.25 \\
\hline S6 & 3.87 & 1.55 & 5.42 & 3.77 & 1.50 & 5.28 & 3.87 & 1.56 & 5.43 \\
\hline
\end{tabular}

${ }^{a}$ Refer Table 1 for detail scenario description. NA: Not applicable. S1-Conventional tillage (CT) without residue; S2-CT with residue, S3- Reduced tillage (RT) with residue + Recommended dose of fertilizer (RDF); S4- RT/zero tillage (ZT) with residue + RDF, S5-ZT with residue + RDF + green seeker + tensiometer +Information \& communication technology +crop insurance and S6-S5 + site specific nutrient management.

\subsection{Fertilizer Management}

In this region, the recommended dose of nitrogen $(\mathrm{N})$, phosphorus $(\mathrm{P})$ and potash $(\mathrm{K})$ for both the crops (rice and wheat) was 150:60:40 $\mathrm{kg} \mathrm{N}, \mathrm{P}_{2} \mathrm{O}_{5}$ and $\mathrm{K}_{2} \mathrm{O} \mathrm{ha}^{-1}$, but farmers usually apply lower doses compared to recommend doses (Table 2). In rice crop in S1 and S2 scenarios, the full dose of $\mathrm{P}$ and $\mathrm{K}$ were applied at the time of transplanting and half dose of $\mathrm{N}$ was applied at active tillering stage (20-25 days after transplanting-DAT) and the remaining half dose was applied at panicle initiation (40-45 DAT). In wheat, a full dose of $\mathrm{P}$ and $\mathrm{K}$ were applied at the time of sowing while $\mathrm{N}$ was applied through urea and was applied in two equal splits at the time of first and second irrigation (Tables 1 and 2). In Scenario 3 and 4, the full dose of $P$ was applied at the time of sowing with seed drill and the full dose of $\mathrm{K}$ and 1/3 of $\mathrm{N}$ was top-dressed at 15-18 days after sowing (DAS) and the remaining dose of $\mathrm{N}$ was applied in two equal splits at active tillering stage (40-DAS) and at panicle stage (55-60-DAS) in direct seeded rice (DSR). A foliar spray of iron sulphate $\left(\mathrm{FeSO}_{4}\right) @ 0.5 \%$ was also done at 20 DAS in rice. In wheat, NPK complex fertilizer was applied as basal and the full dose of $\mathrm{K}$ and $1 / 3$ dose of $\mathrm{N}$ was applied through urea at first irrigation (25 DAS), second irrigation (45 DAS) and third irrigation (65-70 DAS) (Table 2). In scenario 5, the full dose of P and K and first dose of $\mathrm{N}$ was applied to both the crops alike in scenario 3. In S5 and S6, the second and third dose of $\mathrm{N}$ was applied on the basis of normalized difference vegetative index (NDVI) guided at 62 and 65 days after sowing in rice and wheat, respectively [22,23]. In S6, Nutrient Expert ${ }^{\circledR}$ tool was used for scheduling and balancing of NPK fertilizer [24,25]. In scenarios 5 and 6, the area was levelled 
using the laser assistant land leveler before the establishment of the experiment. Short term weather forecast and information and communication technologies (ICT) through voice messages broadcasted by Kishan Sanchar limited were used to schedule the irrigation and other inputs applications like fertilizer, herbicide and insecticides in scenarios 5 and 6 (Table 1).

\subsection{Weed Management}

In the zero tillage system, non-selective herbicide glyphosate @1000 $\mathrm{g}$ a.i. ha ${ }^{-1}$, was used before sowing. In direct seeded rice (DSR), Pendimethalin @1000 g a.i. ha ${ }^{-1}$ was applied as pre-emergence and Bispyribac Sodium 10\% SP + Pyrazosulfuronethly 10\% WP (8-10 g +6 g a.i. ha ${ }^{-1}$, respectively), at 20-25 DAS to control the weeds. All types' weeds were effectively controlled by above pre- and post-emergence herbicides in DSR; remaining weeds were removed by manual hand weeding during the crop growth. In PTR, only one hand weeding was done to control the weeds. In wheat crop to control the weeds, a tank mix solution of Clodinafop-ethyl + Metsulfuron $\left(60+4 \mathrm{~g}\right.$ a.i. ha $\left.{ }^{-1}\right)$ was applied at 30-35 DAS.

\subsection{Yield Data and Economics}

Wheat and rice crop harvested manually as per the treatment description. For grain and straw yields, a $5 \times 5 \mathrm{~m}^{2}$ area was manually harvested from randomly selected 3 places of a plot. The wheat yield converted into rice equivalent yield (REY) to calculate the system yield $\left(\mathrm{t} \mathrm{ha}^{-1}\right)$ and it was computed using equation 1 .

$$
\operatorname{REY}\left(\mathrm{t} \mathrm{ha}^{-1}\right)=\left[\left\{\text { Wheat yield }\left(\mathrm{t} \mathrm{ha}^{-1}\right) \times \text { Wheat MSP }\left(\operatorname{INR~}^{-1}\right)\right\} / \text { Rice MSP }\left(\operatorname{INR}^{-1}\right)\right]
$$

where MSP is the Minimum Support Price (Table 4); INR is the India National Rupee. The variable costs included human labor, tractor operational charges and input costs like seed, fertilizer, pesticides, irrigation, harvesting and threshing were used to calculate economics. The total production cost calculated by the sum of all the variable costs. Gross returns were calculated as per the minimum support price of the crops for grain and prevailing market prices of the straw in different years (Table 4). Net returns were obtained by subtracting the total cost of cultivation from the gross returns.

\subsection{Irrigation Water Management}

The source of irrigation was tube well and $1 \mathrm{HP}$ diesel engine was used for pumping groundwater to irrigate the rice and wheat crops. Each plot was separately irrigated by using Polyvinyl chloride (PVC) delivery pipeline. For irrigation water measurement, on-line water meter (Woltman ${ }^{\circledR}$ helical turbine) was installed at the engine outlet. The amount of irrigation water applied in each plot was computed as per the method described by Reference [8]. Water meter readings were recorded at the start and at the end irrigation to calculate the amount of irrigation water applied per plot. The amount of irrigation water applied was calculated as water depth $\left(\mathrm{mm} \mathrm{ha}^{-1}\right)$ by using Equations (2) and (3), while, irrigation water productivity $\left(\mathrm{WP}_{\mathrm{I}}\right)$ and total (irrigation + rainfall) water productivity $\left(\mathrm{WP}_{\mathrm{I}+\mathrm{R}}\right)$ using Equations (4) and (5).

The volume of irrigation water $\left(\right.$ kiloliter $\left.\mathrm{ha}^{-1}\right)=\{($ Final water meter reading-Initial water meter reading)/Plot area in $\left.\mathrm{m}^{2}\right\} * 10000$

Irrigation water $\left(\mathrm{mm} \mathrm{ha}^{-1}\right)=$ Volume of irrigation water $\left(\right.$ kiloliter ha $\left.{ }^{-1}\right) / 10$

WPI $\left(\mathrm{kg}\right.$ grain $\left.\mathrm{m}^{-3}\right)=$ Grain yield $\left(\mathrm{kg} \mathrm{ha}^{-1}\right) /$ Irrigation water used $\left(\mathrm{m}^{3} \mathrm{ha}^{-1}\right)$

$$
\mathrm{WPI}+\mathrm{R}\left(\mathrm{kg} \text { grain } \mathrm{m}^{-3}\right)=\text { Grain yield }\left(\mathrm{kg} \mathrm{ha}^{-1}\right) / \text { Irrigation }+ \text { rainfall water used }\left(\mathrm{m}^{3} \mathrm{ha}^{-1}\right)
$$

where, 1 ha-mm irrigation depth $=10 \mathrm{kl}=10,000 \mathrm{~L}=10 \mathrm{~m}^{3}$ 
Table 4. Cost/price of key inputs and outputs used for economic analysis during the different years.

\begin{tabular}{|c|c|c|c|}
\hline \multirow{2}{*}{ Item/Commodity } & \multicolumn{3}{|c|}{ Cost/Price (INR Unit ${ }^{-1}$ ) } \\
\hline & 2014-15 & 2015-16 & 2016-17 \\
\hline Rice grain $\left(\mathrm{kg}^{-1}\right)$ & 13.5 & 13.5 & 14.5 \\
\hline Rice residue $\left(\mathrm{kg}^{-1}\right)$ & 1.0 & 0.75 & 1.5 \\
\hline Rice seed $\left(\mathrm{kg}^{-1}\right)$ Rajshree/Arize 6444 Gold & $40 / 250$ & $40 / 250$ & $40 / 250$ \\
\hline Wheat grain $\left(\mathrm{kg}^{-1}\right)$ & 14.5 & 15.0 & 15.5 \\
\hline Wheat residue $\left(\mathrm{kg}^{-1}\right)$ & 3.5 & 4.0 & 4.0 \\
\hline Wheat seed $\left(\mathrm{kg}^{-1}\right)$ PBW 343/HD2967 & $25 / 32$ & $25 / 32$ & $25 / 40$ \\
\hline Urea $\left(\mathrm{kg}^{-1}\right)$ & 5.8 & 5.8 & 5.8 \\
\hline Di-ammonium-phosphate (DAP) $\left(\mathrm{kg}^{-1}\right)$ & 23 & 23 & 23 \\
\hline Muriate of potash (MOP) $\left(\mathrm{kg}^{-1}\right)$ & 16.2 & 16.2 & 16.2 \\
\hline NPK Complex $\left(\mathrm{kg}^{-1}\right)$ & 24 & 24 & 24 \\
\hline Zinc sulphate $\left(\mathrm{ZnSO}_{4}\right)\left(\mathrm{kg}^{-1}\right)$ & 40 & 40 & 40 \\
\hline Glyphosate (Litre ${ }^{-1}$ ) & 280 & 280 & 300 \\
\hline Pendimethalin $\left(\right.$ Liter $\left.^{-1}\right)$ & 220 & 220 & 280 \\
\hline Bispyribac Sodium $\left(\mathrm{mL}^{-1}\right)$ & 7.25 & 6.50 & 6.50 \\
\hline Pyrazosulfuronethly $\left(\mathrm{g}^{-1}\right)$ & 2.50 & 2.75 & 2.75 \\
\hline Clodinafop-ethyl + Metsulfuron $\left(\mathrm{g}^{-1}\right)$ & 2.20 & 2.25 & 2.25 \\
\hline Harrowing $\left(\mathrm{ha}^{-1}\right)$ & 1650 & 1650 & 1650 \\
\hline Cultivator $\left(\mathrm{ha}^{-1}\right)$ & 1000 & 1000 & 1000 \\
\hline Planking $\left(\mathrm{ha}^{-1}\right)$ & 500 & 500 & 500 \\
\hline Puddler $\left(\right.$ ha $\left.^{-1}\right)$ & 3850 & 3850 & 3850 \\
\hline Rotavator $\left(\mathrm{ha}^{-1}\right)$ & 1925 & 1925 & 1925 \\
\hline Seed drill $\left(\mathrm{ha}^{-1}\right)$ & 2200 & 2200 & 2200 \\
\hline Minimum support price (MSP) for rice $\left(\mathrm{kg}^{-1}\right)$ & 13.6 & 14.1 & 14.7 \\
\hline Minimum support price (MSP) for wheat $\left(\mathrm{kg}^{-1}\right)$ & 14.5 & 15.25 & 16.25 \\
\hline Wages Rate (person ${ }^{-1}$ day $^{-1}$ ) & 193 & 204 & 211 \\
\hline USD (\$) to INR Conversation rate & 66 & 66 & 66 \\
\hline
\end{tabular}

In scenarios 4, 5 and 6, irrigation was applied with $\sim 4 \mathrm{~cm}$ depth, however, in scenarios 1, 2 and 3, it was applied with $\sim 6 \mathrm{~cm}$ depth. In scenarios 5 and 6 to monitor the soil metric potential gauge-type tensiometer was installed with the $5 \mathrm{~m}$ distance from bund (Table 2). The tensiometer is the most common sensor for measurement of soil matric potential. In S5 and S6, tensiometers in each treatment (LT1 $30 \mathrm{~cm}$, Irrometer, CA, USA) were installed (one per experimental unit/replication). The irrigation scheduling was based on the reading of tensiometer in kilo Pascal $(\mathrm{kPa})$. The irrigation in rice crop was applied at 20-30 kPa and 40-50 kPa in the case of wheat crop. The irrigation scheduling in the S5 and S6 based on advisories disseminate on weather forecasting by Department of Agriculture, Government of Bihar in the form of voice message received on farmer's cell phones.

\subsection{Energy Analysis}

All inputs and outputs (grain and straw) were used for the energy calculation. The total energy of crops and cropping systems was calculated by using total inputs used like human labor, machinery, diesel, fertilizer, pesticides, seed, irrigation and so forth. Energy equivalents used for estimation of 
energy efficiency from inputs and outputs are given in Table 5. Based on the energy equivalents of the inputs and outputs (Table 5), energy use efficiency and energy productivity were calculated using Equations (6) and (7) [26,27].

Energy use efficiency $\left(\mathrm{MJ}^{-1} \mathrm{MJ}^{-1}\right)=$ Total energy Output $\left(\mathrm{MJ} \mathrm{ha}^{-1}\right) /$ Total energy Input $\left(\mathrm{MJ} \mathrm{ha}^{-1}\right)$

Energy productivity $\left(\mathrm{kg} \mathrm{MJ}^{-1}\right)=$ Grain output $\left(\mathrm{kg} \mathrm{ha}^{-1}\right) /$ Total energy input $\left(\mathrm{MJ} \mathrm{ha}^{-1}\right)$

Table 5. Energy equivalents used for calculation of energy input and output in this study.

\begin{tabular}{|c|c|c|c|}
\hline Particulars & Unit & $\begin{array}{l}\text { Energy Equivalent } \\
\text { (MJ Unit }^{-1} \text { ) }\end{array}$ & Reference \\
\hline \multicolumn{4}{|l|}{ A. Input } \\
\hline Human labor & Man-hour & 1.96 & Parihar et al. (2017) \\
\hline Diesel & Liter & 56.31 & Parihar et al. (2018) \\
\hline Nitrogen (N) & $\mathrm{kg}$ & 66.14 & Gathala et al. (2016) \\
\hline Phosphorus $\left(\mathrm{P}_{2} \mathrm{O}_{5}\right)$ & $\mathrm{kg}$ & 22.44 & Gathala et al. (2016) \\
\hline Potassium $\left(\mathrm{K}_{2} \mathrm{O}\right)$ & $\mathrm{kg}$ & 11.15 & Gathala et al. (2016) \\
\hline Herbicides, insecticides and pesticides & $\mathrm{kg}$ & 120 & Gathala et al. (2016) \\
\hline Irrigation water & ha-cm & 143.56 & Gathala et al. (2016) \\
\hline Zinc sulphate $\left(\mathrm{ZnSO}_{4}\right)$ & $\mathrm{kg}$ & 8.4 & Argiro et al. (2006) \\
\hline Iron sulphate $\left(\mathrm{FeSO}_{4}\right)$ & $\mathrm{kg}$ & 110 & Argiro et al. (2006) \\
\hline Rice/Wheat seed & $\mathrm{kg}$ & 14.7 & Ozkan et al. (2004) \\
\hline \multicolumn{4}{|l|}{ B. Output } \\
\hline Rice and Wheat grain & $\mathrm{kg}$ & 14.7 & Ozkan et al. (2004) \\
\hline Rice and Wheat Straw & $\mathrm{kg}$ & 12.5 & Ozkan et al. (2004) \\
\hline
\end{tabular}

\subsection{Greenhouse Gases (GHGs) Emission Analysis}

The GHGs emissions were calculated by using Climate Change Agriculture and Food Security (CCAFS)-Mitigation Options Tool-MOT developed in collaboration with the University of Aberdeen [28] which calculates the performance of the production system from the GHG emission perspective both in terms of land use efficiency and efficiency per unit of product. The model calculates the fertilizerinduced emissions of nitrous oxide $\left(\mathrm{N}_{2} \mathrm{O}\right)$ and nitric oxide emissions on the basis of the multivariate empirical model [29] and ammonia $\left(\mathrm{NH}_{3}\right)$ emission by the [30] Model. Emission through crop residues returned into the soil was calculated by using Intergovernmental Panel on Climate Change (IPCC) $\mathrm{N} 2 \mathrm{O}$ Tier 1 emission factors. In the same way, the model calculates emissions from the production and transportation of fertilizer were based on the ecoinvent database. Changes in soil carbon (C) attributable to tillage and residue management are based on IPCC principles as seen in References [31] and [32]. The model-estimated emissions of $\mathrm{CO}_{2}$ from soil resulted through urea application is computed as per the IPCC method [33]. To calculate the global warming potential (GWP), all GHGs are transformed into $\mathrm{CO}_{2}$-equivalents $\left(\mathrm{CO}_{2}\right.$ eq.) using 34 and $298 \mathrm{GWP}$ for $\mathrm{CH}_{4}$ and $\mathrm{N}_{2} \mathrm{O}$, respectively [34]. Yield-scaled GWP of both the crops was estimated by dividing the total GWP with the yield of the respective crop.

$$
\left.\operatorname{GWP}\left(\mathrm{kg} \mathrm{CO}_{2} \text {-eq. ha }{ }^{-1}\right)=\mathrm{CO}_{2}\left(\mathrm{~kg} \mathrm{ha}^{-1}\right)+\mathrm{N}_{2} \mathrm{O}\left(\mathrm{kg} \mathrm{ha}^{-1}\right) \times 298+\mathrm{CH}_{4}\left(\mathrm{~kg} \mathrm{ha}^{-1}\right) \times 34\right)
$$

\subsection{Statistical Analysis}

The analysis of all the data was performed with the help of analysis of variance (ANOVA) technique [35] for the randomized complete block design using SAS 9.3 software [36]. The least significant difference test was used to decipher the effects of treatments at a $5 \%$ level of significance $(p \leq 0.05)$. Accordingly, in all tables, results labeled with the same letter are not statistically different. 


\section{Results}

\subsection{Weather}

The climatic conditions at the study site were quite erratic during the study period. The pattern in rainfall was relatively variable. During the 3-year experimentation period (2014 to 2017), the total rainfall received in rainy and winter season was in the range of $788 \mathrm{~mm}$ to $955 \mathrm{~mm}$, which was lower than to the long-term average $(1157 \mathrm{~mm})$. The distribution of rainfall was also not equal in all the monsoon months (June-September) (Figure 2). The rainfall received in 3-months (June to September) alone contributed to $56-80 \%$ of the total annual rainfall received during the cropping season (Figure 2). The rainfall received in rice season of 2014 was $912 \mathrm{~mm}$, (highest $472 \mathrm{~mm}$ in August), $657 \mathrm{~mm}$ in 2015 (maximum $296 \mathrm{~mm}$ in July) and $921 \mathrm{~mm}$ in 2016 (maximum $375 \mathrm{~mm}$ in September), respectively. Whereas in wheat season (November-April), the amount of rainfall received was $44 \mathrm{~mm}$ in the first year, $6.5 \mathrm{~mm}$ in the second year and $20 \mathrm{~mm}$ in the third year of experimentation. During the study years, the maximum and minimum temperature was almost similar in all the years (Figure 2).

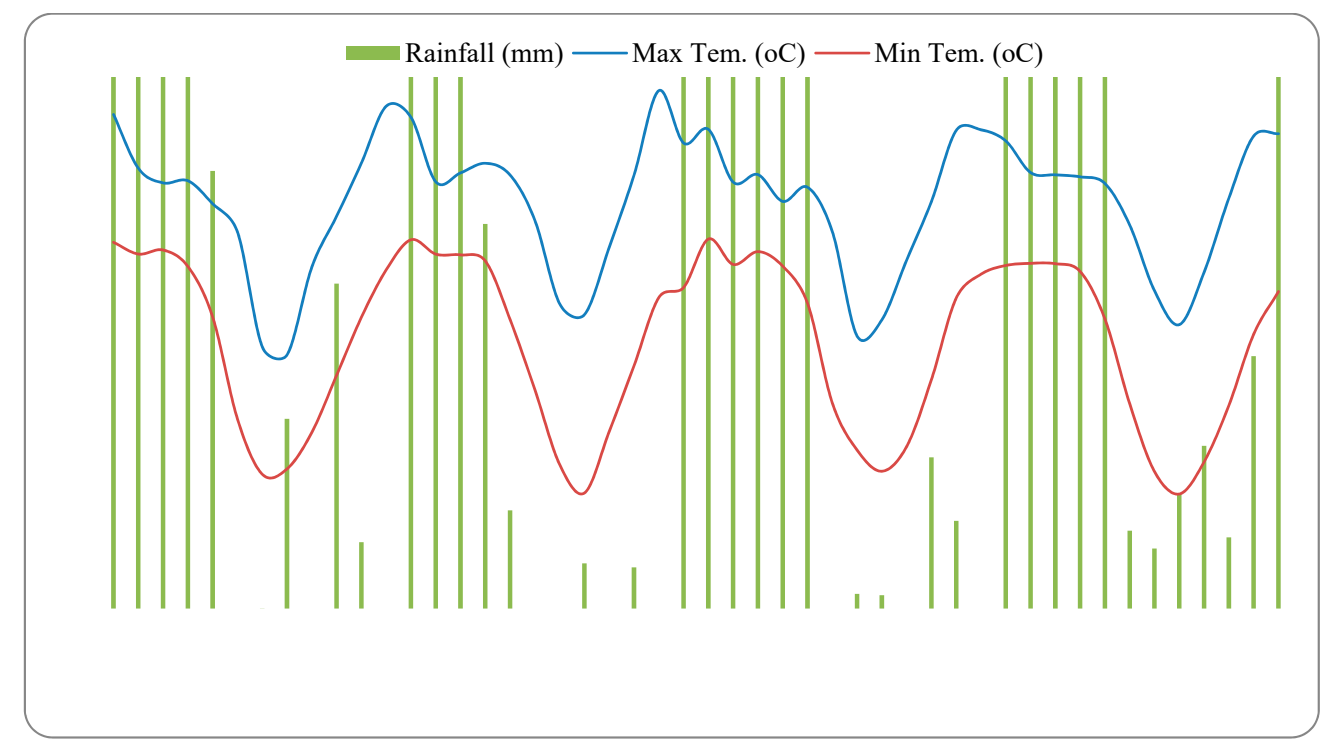

Figure 2. Mean monthly temperature (minimum and maximum) and total rainfall during a three year study period (2014 to 2017) and 35-years long term (1981-2015). Tem. Min.: Minimum Temperature; Tem. Max.: Maximum Temperature; LT-Long term (1981 to 2015).

\subsection{Crop Productivity}

ANOVA showed a non-significant statistical difference $(p \leq 0.05)$ in rice yield under different crop management scenarios in all study years. Even though the rice grains yield statistical similar in all the scenarios during but the maximum yield (5.27-5.78 $\mathrm{t} \mathrm{ha}^{-1}$ ) was recorded with scenario 6 in all the study years (Table 6). Under different scenarios, the 3-year mean grain yield of rice was varied from 5.28 to $5.59 \mathrm{t} \mathrm{ha}^{-1}$. The divergent crop management scenarios layered with diverse crop production practices significantly ( $p \leq 0.05)$ affected the grain yield of succeeding wheat crop in all the study years. The CSAPs (mean of S4, S5 and S6) produced $0.66 \mathrm{t} \mathrm{ha}^{-1}(14.0 \%$ ) higher wheat yields 0.66 across the years compared to farmers practices (FPs; scenarios1, 2 and 3). Under scenario 6, the wheat yield was recorded higher by $21.0 \%, 19.3 \%$ and 10.6\% (3 yrs' mean) compared to S1, S2 and S3, respectively. However, scenarios 4 and 5 recorded 14.6-16.3\% and 7.2\%-15.6\% (3 yrs' mean) higher wheat yield compared to S1 and S2, respectively. Under farmer practice (S1), 5.4\% and 18.2\% lower wheat grain yield was recorded compared to improved farmers practices (mean of S2 and S3) and climate smart agriculture practices (mean of scenario 4, 5 and 6), respectively (Table 6). The system productivity as 
rice equivalents grain yield was recorded higher with CSAPs (scenario 4,5 and 6) compared to farmers practices (FPs) (mean of S1, S2 and S3) in all the 3-years of the study.

Table 6. Effect of different portfolios on yield and economics of rice, wheat and rice-wheat system under divergent crop management scenarios during the 3-year study period.

\begin{tabular}{|c|c|c|c|c|c|c|c|c|c|}
\hline \multirow{2}{*}{ Scenario } & \multicolumn{3}{|c|}{ Grain Yield (t ha-1) } & \multicolumn{3}{|c|}{$\begin{array}{c}\text { Cost of Cultivation (USD } \\
\text { ha }^{-1} \text { ) }\end{array}$} & \multicolumn{3}{|c|}{ Net Return (USD ha-1) } \\
\hline & Rice & Wheat & $\begin{array}{c}\text { RW } \\
\text { System }\end{array}$ & Rice & Wheat & $\begin{array}{c}\text { RW } \\
\text { System }\end{array}$ & Rice & Wheat & $\begin{array}{c}\text { RW } \\
\text { System }\end{array}$ \\
\hline \multicolumn{10}{|l|}{ 2014-15 } \\
\hline $\mathrm{S} 1$ & 5.73 & $4.42^{b}$ & $10.44^{\mathrm{b}}$ & 846.30 & 586.08 & 1432.37 & $447.08^{\mathrm{b}}$ & $752.26^{\mathrm{c}}$ & $1199.34^{d}$ \\
\hline S2 & 5.75 & $4.45^{\mathrm{b}}$ & $10.49^{b}$ & 839.01 & 573.23 & 1412.24 & $416.47^{\mathrm{b}}$ & $700.39^{c}$ & $1116.87^{\mathrm{d}}$ \\
\hline S3 & 5.65 & $5.13^{\mathrm{a}}$ & $11.12^{\mathrm{a}}$ & 669.64 & 592.75 & 1262.39 & $565.71^{\mathrm{a}}$ & $866.97^{\mathrm{b}}$ & $1432.68^{c}$ \\
\hline S4 & 5.63 & $5.26^{\mathrm{a}}$ & $11.24^{\mathrm{a}}$ & 668.08 & 572.5 & 1240.58 & $561.84^{\mathrm{a}}$ & $924.12^{a b}$ & $1485.96^{\mathrm{bc}}$ \\
\hline S5 & 5.69 & $5.31^{\mathrm{a}}$ & $11.35^{\mathrm{a}}$ & 642.93 & 569.43 & 1212.37 & $601.43^{a}$ & $924.99 \mathrm{ab}$ & $1526.42^{a b}$ \\
\hline S6 & 5.78 & $5.46^{\mathrm{a}}$ & $11.60^{\mathrm{a}}$ & 644.52 & 566.91 & 1211.42 & $620.22^{a}$ & $960.39^{a}$ & $1580.61^{a}$ \\
\hline$p$-value & 0.9622 & 0.0003 & 0.0025 & $<0.0001$ & 0.228 & $<0.0001$ & 0.0009 & 0.0002 & $<0.0001$ \\
\hline \multicolumn{10}{|l|}{$2015-16$} \\
\hline S1 & 4.99 & $4.46^{c}$ & $9.81^{\mathrm{c}}$ & 802.80 & 617.80 & 1420.60 & $345.88^{b}$ & $822.23^{b c}$ & $1168.12^{c}$ \\
\hline S2 & 4.98 & $4.59^{c}$ & $9.94^{c}$ & 796.68 & 608.14 & 1404.82 & $320.18^{b}$ & $783.16^{c}$ & $1103.34^{c}$ \\
\hline S3 & 5.15 & $4.81^{b c}$ & $10.35^{b c}$ & 644.76 & 598.05 & 1242.81 & $506.72^{a}$ & $866.95^{b}$ & $1373.68^{b}$ \\
\hline S4 & 5.18 & $5.17^{\mathrm{ab}}$ & $10.77^{a b}$ & 646.26 & 589.08 & 1235.34 & $514.92^{\mathrm{a}}$ & $973.21^{\mathrm{a}}$ & $1488.13^{a b}$ \\
\hline S5 & 5.16 & $5.21^{\mathrm{ab}}$ & $10.80^{\mathrm{ab}}$ & 616.97 & 588.00 & 1204.97 & $540.86^{a}$ & $977.20^{\mathrm{a}}$ & $1518.06^{a}$ \\
\hline S6 & 5.27 & $5.38^{a}$ & $11.09^{\mathrm{a}}$ & 614.94 & 592.46 & 1207.41 & $566.30^{a}$ & $1014.77^{\mathrm{a}}$ & $1581.06^{\mathrm{a}}$ \\
\hline$p$-value & 0.5429 & 0.0033 & 0.0075 & $<0.0001$ & 0.0492 & $<0.0001$ & $<0.0001$ & 0.0004 & $<0.0001$ \\
\hline \multicolumn{10}{|l|}{ 2016-17 } \\
\hline S1 & 5.13 & $4.67^{b}$ & $10.29^{c}$ & 881.72 & 642.18 & 1523.90 & $427.04^{c}$ & $910.54^{b}$ & $1337.58^{d}$ \\
\hline S2 & 5.21 & $4.70^{\mathrm{b}}$ & $10.41^{\mathrm{c}}$ & 873.65 & 629.34 & 1502.99 & $395.95^{c}$ & $860.06^{b}$ & $1256.02^{d}$ \\
\hline S3 & 5.32 & $4.88^{b}$ & $10.71^{b c}$ & 705.96 & 615.67 & 1321.63 & $585.41^{b}$ & $925.68^{b}$ & $1511.09^{c}$ \\
\hline S4 & 5.33 & $5.33^{\mathrm{a}}$ & $11.23^{\mathrm{ab}}$ & 705.89 & 614.51 & 1320.40 & $590.47^{\mathrm{b}}$ & $1061.96^{\mathrm{a}}$ & $1652.43^{b c}$ \\
\hline S5 & 5.38 & $5.37^{\mathrm{a}}$ & $11.31^{\mathrm{ab}}$ & 675.80 & 612.37 & 1288.16 & $631.06^{a b}$ & $1075.02^{a}$ & $1706.09 \mathrm{ab}$ \\
\hline S6 & 5.73 & $5.55^{\mathrm{a}}$ & $11.86^{\mathrm{a}}$ & 672.63 & 619.88 & 1292.51 & $714.11^{\mathrm{a}}$ & $1123.69^{a}$ & $1837.80^{a}$ \\
\hline$p$-value & 0.1447 & 0.0028 & 0.0086 & $<0.0001$ & 0.1163 & $<0.0001$ & $<0.0001$ & 0.0007 & $<0.0001$ \\
\hline
\end{tabular}

On 3-yrs' mean basis system productivity in scenario 6 was higher by $13 \%$ and $12 \%$ compared to scenario 1 and scenario 2, respectively. Overall the climate smart agriculture practices improved the RW system productivity by $7 \%$ to $10 \%$ (3-years' mean basis) compared to farmers practices (mean of S1, S2 and S3), respectively. (Table 6).

\subsection{Economics}

The costs of cultivation were mainly attributed to field preparations, fertilizer dose, irrigation and man-days used. In the present, we used farmer's own equipment for tillage operations whereas a rental seed drill machine "happy seeder" was used for the sowing. Among the divergent crop management practices, the cost of cultivation in rice, wheat and RW system was recorded higher under FPs (individually as well as on the mean basis of S1, S2 and S3) compared to CSAPs in all the 3 years of study (Table 6). Individually the cost of cultivation in rice, wheat and RW system was recorded highest with S1 (843, 615 and 1458 USD ha $^{-1} ; 3$-yrs' mean) and S2 (836, 604 and 1440 USD ha $^{-1}$; 3-yrs' mean) and lowest under S5 (645, 590 and 1250 USD ha $^{-1}$; 3-yrs' mean) and S6 $\left(644,593,1252\right.$ USD ha $^{-1}$; 3 -yrs' mean basis), respectively. The CSAPs gave significantly $(p \leq 0.05)$ higher net return compared to farmer's practices in rice, wheat and RW system in all the 3 years (Table 6). In CSAPs (mean of S4, S5 and S6), the net return in rice, wheat and RW system increased by $33 \%, 20 \%$ and $25 \%$ (3-yrs' mean basis) compared to farmer's practice, respectively. During all the 3-years highest net returns of rice 
(566-714 USD ha ${ }^{-1}$ ), wheat (960-1124 USD ha ${ }^{-1}$ ) and RW system (1581-1838 USD ha ${ }^{-1}$ ) were recorded in $\mathrm{S} 6$ compared to other scenarios. RW system net return was substantially increased in all the study years from the FPs (mean of S1, S2 and S3) with different CSAPs and followed the trend of S4 > S5 > S6. (Table 6).

\subsection{Water Use and Water Productivity}

The total water input (irrigation + rainfall) for rice, wheat and RW cropping system was significantly ( $p \leq 0.05$ ) higher by $29.0-50.1 \%, 26.7-44.7 \%$ and $32.8-43.5 \%$ farmers practice plots compared to CSAPs-based (S6) plots during 2014-2015, 2015-2016 and 2016-2017, respectively (Table 7). In rice, the amount of irrigation water applied varied from 344.2 to $485.8 \mathrm{~mm} \mathrm{ha}^{-1}$ and in wheat, it varied from 136.7 to $191.6 \mathrm{~mm} \mathrm{ha}^{-1}$ (on 3-yrs' mean basis). Climate smart agriculture practices (mean of S4, S5 and S6) saved $24 \%$ to $32.7 \%$ and $2.6 \%$ to $31.6 \%$ irrigation water in rice and wheat compared to farmer's practice (S1) in three years of the study, respectively. In the RW system, S1 and S2 utilized the highest amount of applied irrigation water ( $677 \mathrm{~mm}$; on 3-yrs' mean basis), whereas S5 and S6 utilized lowest ( $481 \mathrm{~mm}$; on 3-yrs' mean basis) amount of irrigation water. On an average, CSAPs saved 39.3\% of irrigation water compared to farmer's practice (3-yrs mean of S1) (Table 7). Total water productivity (IW and $+\mathrm{RF}$ ) was recorded higher under CSAPs of rice, wheat and RW system in all the 3-years compared to FP. The S5 and S6 recorded 34.2-38.7\%, 69.5-73.4\% and 51-56.1\% higher irrigation water productivity (3-yrs' mean basis) of rice, wheat and RW system, respectively compared to FP (3-yrs mean of S1). Since water use in the treatments with the tensiometer was substantially lower than in the farmers' practice (S1) in both the crops over the years. However, a corresponding analysis did not reveal any systematic reduction of irrigation water use in the S4 compared to the S5 and S6 due to the less requirement of irrigation water and high frequency of rainfall particularly in kharif season in the region. Also farmers in the region applied irrigation when soil hair line cracks appear in rice which is also same as a tensiometer based irrigation scheduling, based on tensiometer reading. Therefore, tensiometer based irrigation not saved much irrigation water among the treatments but proper guided for scheduling irrigations. Water productivity in the tensiometer-based treatments was significantly higher compared to farmers practice but slightly higher among the treatments layering with CSA technologies (S4, S5 and S6) (Table 7). Probably, the tensiometers do not indicate how much water should be applied but indicate when to irrigate the crop. In the tensiometer treatment, farmers did not irrigate the crop as often as in the other treatments, but they irrigated with higher amounts than necessary. The lower irrigation water in CSA scenarios (S4, S5 and S6) than in puddled transplanted rice (PTR) with alternate wet and dry (AWD) water management in scenarios (S1, S2 and S3) could be explained by PTR with AWD being retained in a continuously flooded condition for the first 15-20 days after transplanting, whereas, in DSR, the fields were kept moist but not continuously flooded. In addition, CSA scenarios no-tillage with residue retention or as mulch conserved soil moisture and hence delayed the application of irrigation, resulting in savings of irrigation water.

\subsection{Energy Utilization Pattern and Efficiency}

The energy utilization, use efficiency and productivity patterns in the rice-wheat system in all the three years was computed with respect to different sources and operations. In all three years of study (2014-2017), the sum of all energy inputs were recorded significantly $(p \leq 0.05)$ higher under farmer's practices in rice $\left(31.7 \times 10^{3} \mathrm{MJ} \mathrm{ha}^{-1}\right.$; 3-yrs means of S1, S2 and S3), wheat $\left(24.1 \times 10^{3} \mathrm{MJ} \mathrm{ha}^{-1}\right.$; 3-yrs mean of S1, S2 and S3) and RW production system (55.8 $\times 10^{3} \mathrm{MJ} \mathrm{ha}^{-1}$; 3-yrs mean of S1, S2 and S3), respectively (Table 8). The S1 and S2 recorded 36.1, 33.3 and 34.9\% (3-yrs' mean) higher energy input compared to $\mathrm{S} 6$ in rice, wheat and RW system, respectively. In all the study years the highest energy output in rice $\left(174.5 \times 10^{3} \mathrm{MJ} \mathrm{ha}^{-1} ; 3\right.$ yrs mean of S4, S5 and S6), wheat $\left(174.1 \times 10^{3} \mathrm{MJ} \mathrm{ha}^{-1} ; 3\right.$ yrs mean of S4, S5 and S6) and RW system (348.6 $\times 10^{3} \mathrm{MJ} \mathrm{ha}^{-1}$; 3-yrs mean of S4, S5 and S6), was recorded with climate smart agriculture practices (mean of S4, S5 and S6). The lowest energy input requirement and highest energy output of rice, wheat and RW system with CSAPs resulted in higher energy productivity 
(EP) as well as energy use efficiency (EUE). Under S6, energy use efficiency and energy productivity was recorded about $42-60 \%$ (3-yrs' mean basis) higher in rice, wheat and RW system as compared to farmers practices (S1). While S2 and S4 scenario recorded intermediate energy input, output, EUE and EP in all the study years. These higher energy outputs related to higher yield and lower energy inputs related to low input used in Scenarios 4, 5 and 6 resulted in higher net energy return than in scenario 1 . Fuel consumption during land preparation and crop establishment also declined significantly in CA-based systems (Scenarios 4-6) compared with CT-based scenario 1. This reduction occurred mainly because of the decrease in the energy required for tillage and crop establishment, irrigation water and fertilizer applied in CSA scenarios compared to FP (Table 8).

\subsection{Global Warming Potential and Carbon Footprints}

The data of the present study indicated that global warming potential (GWP) and $\mathrm{CO}_{2}$ emission intensity of RW system was significantly $(p \leq 0.05)$ influenced by divergent crop management practices. Among the crop management scenarios, $\mathrm{S} 1$ recorded the highest GWP and $\mathrm{CO}_{2}$ emission intensity followed by S2 and the lowest was in $\mathrm{S} 6$ and following overall trend of $\mathrm{S} 6>\mathrm{S} 5>\mathrm{S} 4>\mathrm{S} 3>\mathrm{S} 2>\mathrm{S} 1$ (Figure 3). The higher GWP and $\mathrm{CO}_{2}$ emission intensity in farmer practices scenarios (S1 and S2) reflects the more contributed in carbon footprints. On 3-years mean basis, CSAPs recorded lower GWP by 1598,1749 and $1876.3 \mathrm{~kg} \mathrm{CO}_{2}$ eq. ha ${ }^{-1} \mathrm{yr}^{-1}$ compared to $\mathrm{S} 1\left(3652.7 \mathrm{~kg} \mathrm{CO}_{2}\right.$ eq. ha $\left.{ }^{-1} \mathrm{yr}^{-1}\right)$, respectively. Input like diesel fuel (for land preparation, seeding and irrigation water application), fertilizers constitute and puddling in rice, the major share of the total emissions of GHGs $\left(\mathrm{N}_{2} \mathrm{O}\right.$ and $\mathrm{CH}_{4}$ ) estimated for the system (Figure 3). The CSA based scenarios (S4 S5 and S6) related to low inputs and no puddling in rice contributed to low emissions of GHGs compared to farmers practice (S1), whereas higher input used and followed repeated tillage in wheat and puddling in rice (explained the treatments as in Table 1).
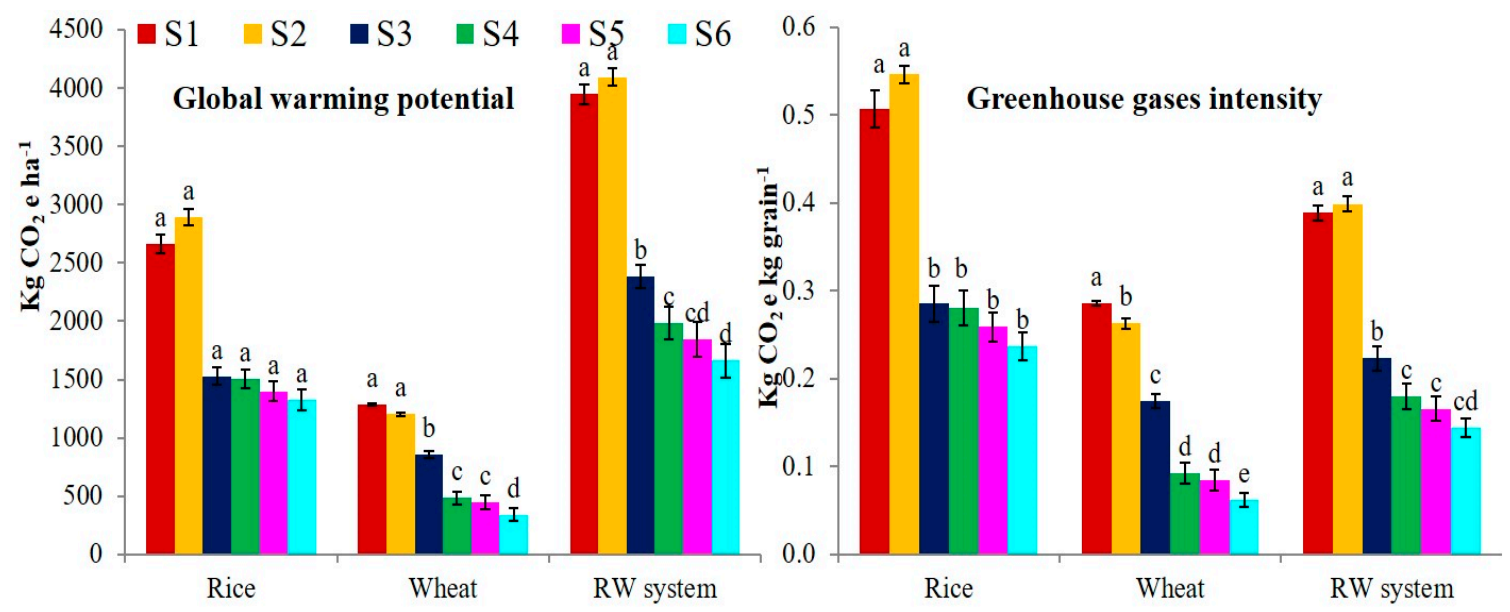

Figure 3. Mean annual global warming potential (GWP) and greenhouse gases intensity of rice-wheat system under divergent crop management scenarios. S1- Conventional tillage (CT) without residue; S2- CT with residue, S3- Reduced tillage (RT) with residue + Recommended dose of fertilizer (RDF); S4- RT/zero tillage (ZT) with residue + RDF, S5-ZT with residue + RDF + green seeker + tensiometer +Information \& communication technology +crop insurance and S6- S5 + site specific nutrient management. Values with different lower case (a-e) letters are significantly different between each scenario at $5 \%$ level of significance $(p \leq 0.05)$. Vertical bars indicate \pm S.E. of mean of the observed values. 
Table 7. Effect of different portfolios on irrigation water use and water productivity under divergent crop management scenarios during a 3-year study.

\begin{tabular}{|c|c|c|c|c|c|c|c|c|c|c|c|c|}
\hline \multirow[t]{2}{*}{ Scenario } & \multicolumn{3}{|c|}{$\begin{array}{l}\text { Irrigation Water Use } \\
\left(\mathrm{mm} \mathrm{ha}^{-1}\right)\end{array}$} & \multicolumn{3}{|c|}{$\begin{array}{l}\text { Rain Fall } \\
\left(\mathrm{mmha}^{-1}\right)\end{array}$} & \multicolumn{3}{|c|}{$\begin{array}{l}\text { Irrigation Water (IW) Productivity } \\
\left(\mathrm{kg} \text { grain } \mathrm{m}^{-3} \text { water) }\right.\end{array}$} & \multicolumn{3}{|c|}{$\begin{array}{c}\text { Total Water Productivity } \\
\text { (IW + Rainfall) } \\
\text { (kg grain } \text { m }^{-3} \text { water) }\end{array}$} \\
\hline & Rice & Wheat & RW System & Rice & Wheat & RW System & Rice & Wheat & RW System & Rice & Wheat & RW System \\
\hline & & & & & & 2014-15 & & & & & & \\
\hline S1 & $489.1^{\mathrm{a}}$ & $191.8^{\mathrm{a}}$ & $680.9^{a}$ & 817.3 & 39.0 & 856.3 & $1.18^{\mathrm{b}}$ & $2.30^{\mathrm{d}}$ & $1.54^{\mathrm{d}}$ & $0.44^{\mathrm{a}}$ & $1.91^{\mathrm{d}}$ & $0.68^{d}$ \\
\hline S2 & $490.5^{\mathrm{a}}$ & $192.2^{\mathrm{a}}$ & $682.7^{\mathrm{a}}$ & 817.3 & 39.0 & 856.3 & $1.18^{\mathrm{b}}$ & $2.32^{\mathrm{d}}$ & $1.54^{\mathrm{d}}$ & 0.44 & $1.92^{\mathrm{d}}$ & $0.68^{d}$ \\
\hline S3 & $338.2^{b}$ & $176.7^{\mathrm{b}}$ & $515.0^{\mathrm{b}}$ & 911.5 & 39.0 & 950.5 & $1.67^{\mathrm{a}}$ & $2.94^{\mathrm{c}}$ & $2.15^{c}$ & $0.45^{\mathrm{a}}$ & $2.37^{c}$ & $0.75 \mathrm{cb}$ \\
\hline S4 & $336.0^{\mathrm{b}}$ & $151.3^{c}$ & $487.3^{c}$ & 911.5 & 39.0 & 950.5 & $1.67^{\mathrm{a}}$ & $3.52^{a b}$ & $2.31^{\mathrm{ab}}$ & $0.45^{\mathrm{a}}$ & $2.79 \mathrm{ab}$ & $0.78^{a b}$ \\
\hline S5 & $325.8^{\mathrm{b}}$ & $149.9^{c}$ & $475.7^{\mathrm{c}}$ & 911.5 & 39.0 & 950.5 & $1.75^{\mathrm{a}}$ & $3.57^{\mathrm{ab}}$ & $2.39^{a}$ & $0.46^{\mathrm{a}}$ & $2.82^{\mathrm{ab}}$ & $0.80^{\mathrm{ab}}$ \\
\hline S6 & $325.8^{\mathrm{b}}$ & $149.9^{c}$ & $475.7^{\mathrm{c}}$ & 911.5 & 39.0 & 950.5 & $1.77^{\mathrm{a}}$ & $3.67^{\mathrm{a}}$ & $2.44^{\mathrm{a}}$ & $0.47^{\mathrm{a}}$ & $2.90^{\mathrm{a}}$ & $0.81^{\mathrm{a}}$ \\
\hline \multirow[t]{2}{*}{$p$-value } & $<0.0001$ & 0.0033 & $<0.0001$ & & & & $<0.0001$ & 0.0001 & $<0.0001$ & 0.5895 & $<0.0001$ & $<0.0001$ \\
\hline & & & & & & 2015-16 & & & & & & \\
\hline S1 & $505.6^{\mathrm{a}}$ & $190.0^{\mathrm{a}}$ & $695.6^{\mathrm{a}}$ & $559.1^{\mathrm{a}}$ & 6.5 & 565.6 & $0.99^{b}$ & $2.34^{c}$ & $1.41^{\mathrm{d}}$ & $0.47^{\mathrm{a}}$ & $2.27^{\mathrm{c}}$ & $0.78^{c}$ \\
\hline S2 & $507.2^{\mathrm{a}}$ & $190.3^{a}$ & $697.5^{\mathrm{a}}$ & $559.1^{\mathrm{a}}$ & 6.5 & 565.6 & $0.98^{\mathrm{b}}$ & $2.41^{\mathrm{c}}$ & $1.43^{\mathrm{d}}$ & $0.47^{\mathrm{a}}$ & $2.33^{c}$ & $0.79^{c}$ \\
\hline S3 & $394.6^{\mathrm{b}}$ & $144.1^{\mathrm{b}}$ & $538.7^{b}$ & $644.8^{a}$ & 6.5 & 651.3 & $1.30^{\mathrm{a}}$ & $3.34^{\mathrm{b}}$ & $1.92^{\mathrm{c}}$ & $0.50^{\mathrm{a}}$ & $3.19^{b}$ & $0.87^{\mathrm{b}}$ \\
\hline S4 & $392.0^{\mathrm{b}}$ & $131.9^{c}$ & $523.9^{\mathrm{c}}$ & $644.8^{a}$ & 6.5 & 651.3 & $1.32^{\mathrm{a}}$ & $3.92^{\mathrm{a}}$ & $2.05^{b}$ & $0.50^{\mathrm{a}}$ & $3.73^{a}$ & $0.92^{\mathrm{ab}}$ \\
\hline S5 & $380.1^{c}$ & $131.3^{c}$ & $511.4^{\mathrm{d}}$ & $644.8^{\mathrm{a}}$ & 6.5 & 651.3 & $1.36^{\mathrm{a}}$ & $3.97^{\mathrm{a}}$ & $2.11^{\mathrm{ab}}$ & $0.50^{\mathrm{a}}$ & $3.78^{\mathrm{a}}$ & $0.93^{\mathrm{a}}$ \\
\hline S6 & $380.1^{c}$ & $131.3^{c}$ & $511.4^{\mathrm{d}}$ & $644.8^{a}$ & 6.5 & 651.0 & $1.39^{\mathrm{a}}$ & $4.10^{\mathrm{a}}$ & $2.17^{a}$ & $0.51^{\mathrm{a}}$ & $3.90^{\mathrm{a}}$ & $0.95^{\mathrm{a}}$ \\
\hline \multirow[t]{2}{*}{$p$-value } & $<0.0001$ & $<0.0001$ & $<0.0001$ & & & & $<0.0001$ & 0.0001 & $<0.0001$ & 0.0842 & $<0.0001$ & $<0.0001$ \\
\hline & & & & & & 2016-17 & & & & & & \\
\hline S1 & $460.6^{\mathrm{a}}$ & $193.0^{\mathrm{a}}$ & $653.6^{a}$ & 787.9 & 20.1 & 808.0 & $1.12^{c}$ & $2.42^{\mathrm{d}}$ & $1.58^{\mathrm{d}}$ & $0.41^{\mathrm{a}}$ & $2.19^{\mathrm{d}}$ & $0.70^{c}$ \\
\hline S2 & $459.7^{\mathrm{a}}$ & $192.4^{\mathrm{b}}$ & $652.1^{\mathrm{a}}$ & 787.9 & 20.1 & 808.0 & $1.14^{c}$ & $2.44^{\mathrm{d}}$ & $1.60^{\mathrm{d}}$ & $0.42^{\mathrm{a}}$ & $2.21^{\mathrm{d}}$ & $0.71^{c}$ \\
\hline S3 & $341.0^{\mathrm{b}}$ & $149.9^{\mathrm{c}}$ & $490.9^{b}$ & 899.3 & 20.1 & 919.4 & $1.56^{\mathrm{b}}$ & $3.25^{c}$ & $2.18^{c}$ & $0.43^{\mathrm{a}}$ & $2.87^{c}$ & $0.76^{b c}$ \\
\hline S4 & $337.4^{\mathrm{bc}}$ & $138.5^{\mathrm{d}}$ & $475.9^{\mathrm{c}}$ & 899.3 & 20.1 & 919.4 & $1.58^{\mathrm{b}}$ & $3.85^{b}$ & $2.36^{\mathrm{b}}$ & $0.43^{\mathrm{a}}$ & $3.36^{\mathrm{b}}$ & $0.80^{\mathrm{ab}}$ \\
\hline S5 & $327.4^{c}$ & $128.9^{\mathrm{f}}$ & $456.3^{d}$ & 899.3 & 20.1 & 919.4 & $1.64^{\mathrm{ab}}$ & $4.16^{\mathrm{a}}$ & $2.48^{\mathrm{ab}}$ & $0.44^{\mathrm{a}}$ & $3.60^{\mathrm{ab}}$ & $0.82^{\mathrm{a}}$ \\
\hline S6 & $326.6^{c}$ & $128.9^{\mathrm{e}}$ & $455.5^{\mathrm{d}}$ & 899.3 & 20.1 & 919.4 & $1.75^{\mathrm{a}}$ & $4.30^{\mathrm{a}}$ & $2.60^{\mathrm{a}}$ & $0.47^{\mathrm{a}}$ & $3.72^{\mathrm{a}}$ & $0.86^{\mathrm{a}}$ \\
\hline$p$-value & $<0.0001$ & $<0.0001$ & $<0.0001$ & & & & $<0.0001$ & 0.0001 & $<0.0001$ & 0.0941 & $<0.0001$ & 0.0007 \\
\hline
\end{tabular}

S1-Conventional tillage (CT) without residue; S2-CT with residue, S3-Reduced tillage (RT) with residue + Recommended dose of fertilizer (RDF); S4-RT/zero tillage (ZT) with residue + RDF

lower case (a-f) letters are significantly different between each scenario at $5 \%$ level of significance $(p \leq 0.05)$. 
Table 8. Effect of different crop management scenarios on input and output energy, energy use efficiency and energy productivity during a 3-year study.

\begin{tabular}{|c|c|c|c|c|c|c|c|c|c|c|c|c|}
\hline \multirow{2}{*}{ Scenario } & \multicolumn{3}{|c|}{$\begin{array}{c}\text { Energy Input } \times 10^{3} \\
\left(\mathrm{MJ} \mathrm{ha}^{-1}\right)\end{array}$} & \multicolumn{3}{|c|}{$\begin{array}{c}\text { Energy Output } \times 10^{3} \\
\left(\mathrm{MJ} \mathrm{ha}^{-1}\right)\end{array}$} & \multicolumn{3}{|c|}{$\begin{array}{c}\text { Energy Use Efficiency } \\
\left(\mathrm{MJMJ}^{-1}\right)\end{array}$} & \multicolumn{3}{|c|}{$\begin{array}{c}\text { Energy Productivity } \\
\left(\mathrm{Kg} \mathrm{MJ}^{-1}\right)\end{array}$} \\
\hline & Rice & Wheat & RW System & Rice & Wheat & RW System & Rice & Wheat & RW System & Rice & Wheat & RW System \\
\hline \multicolumn{13}{|l|}{ 2014-15 } \\
\hline S1 & $34.70^{\mathrm{a}}$ & $23.65^{\mathrm{a}}$ & $58.35^{a}$ & 176.96 & $151.56^{\mathrm{b}}$ & $328.52^{b}$ & $5.16^{\mathrm{c}}$ & $6.41^{\mathrm{d}}$ & $5.65^{\mathrm{d}}$ & $0.17^{c}$ & $0.19^{\mathrm{d}}$ & $0.18^{\mathrm{d}}$ \\
\hline S2 & $34.64^{\mathrm{a}}$ & $23.65^{\mathrm{a}}$ & $58.29^{a}$ & 179.03 & $152.73^{b}$ & $331.77^{b}$ & $5.20^{c}$ & $6.46^{\mathrm{d}}$ & $5.70^{\mathrm{d}}$ & $0.17^{c}$ & $0.19^{d}$ & $0.18^{\mathrm{d}}$ \\
\hline S3 & $30.84^{\mathrm{b}}$ & $23.41^{\mathrm{a}}$ & $54.25^{\mathrm{b}}$ & 176.81 & $173.58^{\mathrm{a}}$ & $350.39^{a}$ & $5.75^{\mathrm{b}}$ & $7.43^{c}$ & $6.46^{\mathrm{c}}$ & $0.18^{\mathrm{b}}$ & $0.22^{c}$ & $0.20^{c}$ \\
\hline S4 & $29.50^{\mathrm{b}}$ & $20.53^{b}$ & $50.03^{c}$ & 176.06 & $177.56^{\mathrm{a}}$ & $353.62^{\mathrm{a}}$ & $5.98^{b}$ & $8.68^{b}$ & $7.07^{b}$ & $0.19^{b}$ & $0.26^{\mathrm{b}}$ & $0.22^{b}$ \\
\hline S5 & $26.52^{c}$ & $19.05^{c}$ & $45.57^{\mathrm{d}}$ & 177.91 & $174.72^{a}$ & $352.63^{\mathrm{a}}$ & $6.74^{\mathrm{a}}$ & $9.17^{\mathrm{ab}}$ & $7.75^{\mathrm{a}}$ & $0.22^{\mathrm{a}}$ & $0.28^{a}$ & $0.25^{\mathrm{a}}$ \\
\hline S6 & $25.78^{c}$ & $18.61^{c}$ & $44.39^{d}$ & 181.82 & $176.97^{\mathrm{a}}$ & $358.79^{a}$ & $7.07^{\mathrm{a}}$ & $9.52^{\mathrm{a}}$ & $8.09^{a}$ & $0.22^{\mathrm{a}}$ & $0.29^{a}$ & $0.26^{\mathrm{a}}$ \\
\hline$p$-value & $<0.0001$ & $<0.0001$ & $<0.0001$ & 0.8723 & 0.0019 & 0.0042 & $<0.0001$ & $<0.0001$ & $<0.0001$ & $<0.0001$ & $<0.0001$ & $<0.0001$ \\
\hline \multicolumn{13}{|l|}{$2015-16$} \\
\hline S1 & $31.57^{\mathrm{a}}$ & $24.76^{\mathrm{a}}$ & $56.34^{a}$ & 165.13 & $150.14^{c}$ & $315.27^{c}$ & $5.28^{\mathrm{c}}$ & $6.06^{\mathrm{e}}$ & $5.61^{d}$ & $0.16^{\mathrm{c}}$ & $0.18^{\mathrm{e}}$ & $0.17^{\mathrm{e}}$ \\
\hline S2 & $31.49^{\mathrm{a}}$ & $24.76^{\mathrm{a}}$ & $56.26^{\mathrm{a}}$ & 162.04 & $152.94^{c}$ & $314.98^{c}$ & $5.18^{c}$ & $6.18^{\mathrm{e}}$ & $5.62^{d}$ & $0.16^{c}$ & $0.19 \mathrm{de}$ & $0.18^{\mathrm{e}}$ \\
\hline S3 & $29.44^{\mathrm{ab}}$ & $23.65^{b}$ & $53.08^{b}$ & 164.99 & $161.97^{b}$ & $326.96^{b c}$ & $5.60 \mathrm{bc}$ & $6.86^{\mathrm{d}}$ & $6.16^{\mathrm{d}}$ & $0.17^{b c}$ & $0.20^{\mathrm{d}}$ & $0.19^{\mathrm{d}}$ \\
\hline S4 & $28.21^{b}$ & $20.56^{c}$ & $48.77^{c}$ & 168.87 & $170.99^{a}$ & $339.86^{\mathrm{ab}}$ & $5.98^{\mathrm{b}}$ & $8.32^{c}$ & $6.97^{c}$ & $0.18^{\mathrm{b}}$ & $0.25^{c}$ & $0.22^{c}$ \\
\hline S5 & $24.18^{c}$ & $19.09^{\mathrm{d}}$ & $43.27^{\mathrm{d}}$ & 168.68 & $\begin{array}{c}169.68 \\
a b\end{array}$ & $338.36^{a b}$ & $6.98^{\mathrm{a}}$ & $8.89^{b}$ & $7.82^{b}$ & $0.21^{\mathrm{a}}$ & $0.27^{b}$ & $0.25^{b}$ \\
\hline S6 & $23.02^{c}$ & $18.14^{\mathrm{e}}$ & $41.16^{\mathrm{d}}$ & 171.79 & $172.93^{\mathrm{a}}$ & $344.72^{\mathrm{a}}$ & $7.46^{\mathrm{a}}$ & $9.54^{\mathrm{a}}$ & $8.38^{\mathrm{a}}$ & $0.23^{\mathrm{a}}$ & $0.30^{\mathrm{a}}$ & $0.27^{\mathrm{a}}$ \\
\hline$p$-value & $<0.0001$ & $<0.0001$ & $<0.0001$ & 0.6614 & 0.0006 & 0.0102 & $<0.0001$ & $<0.0001$ & $<0.0001$ & $<0.0001$ & $<0.0001$ & $<0.0001$ \\
\hline \multicolumn{13}{|l|}{ 2016-17 } \\
\hline S1 & $31.57^{\mathrm{a}}$ & $24.76^{\mathrm{a}}$ & $56.34^{\mathrm{a}}$ & 166.98 & $151.70^{b}$ & $318.68^{d}$ & $5.32^{d}$ & $6.13^{e}$ & $5.67^{\mathrm{d}}$ & $0.16^{\mathrm{d}}$ & $0.19^{\mathrm{d}}$ & $0.18^{\mathrm{d}}$ \\
\hline S2 & $31.49^{\mathrm{a}}$ & $24.76^{\mathrm{a}}$ & $56.26^{\mathrm{a}}$ & 168.99 & $154.65^{\mathrm{b}}$ & $323.63^{\mathrm{cd}}$ & $5.40^{\mathrm{cd}}$ & $6.25^{\mathrm{de}}$ & $5.77^{\mathrm{d}}$ & $0.17^{\mathrm{cd}}$ & $0.19^{d}$ & $0.19^{\mathrm{d}}$ \\
\hline S3 & $29.44^{\mathrm{ab}}$ & $23.65^{\mathrm{b}}$ & $53.08^{b}$ & 170.14 & $159.52^{b}$ & $329.66^{\mathrm{bcd}}$ & $5.78^{\mathrm{cd}}$ & $6.75^{\mathrm{d}}$ & $6.21^{\mathrm{d}}$ & $0.18^{\mathrm{cd}}$ & $0.21^{d}$ & $0.20^{\mathrm{d}}$ \\
\hline S4 & $28.21^{b}$ & $20.56^{c}$ & $48.77^{\mathrm{c}}$ & 171.40 & $172.11^{\mathrm{a}}$ & $343.51^{a b c}$ & $6.08^{\mathrm{c}}$ & $8.38^{\mathrm{c}}$ & $7.04^{c}$ & $0.19^{\mathrm{c}}$ & $0.26^{\mathrm{c}}$ & $0.23^{c}$ \\
\hline S5 & $24.18^{c}$ & $19.09^{\mathrm{d}}$ & $43.27^{\mathrm{d}}$ & 172.60 & $173.24^{a}$ & $345.84 \mathrm{ab}$ & $7.14^{\mathrm{b}}$ & $9.08^{b}$ & $7.99^{b}$ & $0.22^{b}$ & $0.28^{b}$ & $0.26^{b}$ \\
\hline S6 & $23.02^{c}$ & $18.14^{\mathrm{e}}$ & $41.16^{\mathrm{d}}$ & 180.94 & $178.94^{\mathrm{a}}$ & $359.88^{a}$ & $7.86^{\mathrm{a}}$ & $9.87^{\mathrm{a}}$ & $8.74^{\mathrm{a}}$ & $0.25^{\mathrm{a}}$ & $0.31^{\mathrm{a}}$ & $0.29^{a}$ \\
\hline$p$-value & $<0.0001$ & $<0.0001$ & $<0.0001$ & 0.3482 & 0.0015 & 0.0134 & $<0.0001$ & $<0.0001$ & $<0.0001$ & $<0.0001$ & $<0.0001$ & $<.0001$ \\
\hline
\end{tabular}

S1-Conventional tillage (CT) without residue; S2-CT with residue, S3-Reduced tillage (RT) with residue + Recommended dose of fertilizer (RDF); S4-RT/zero tillage (ZT) with residue + RDF, S5-ZT with residue + RDF + green seeker + tensiometer +Information \& communication technology +crop insurance and S6-S5 + site specific nutrient management. Values with different lower case $(a-e)$ letters are significantly different between each scenario at $5 \%$ level of significance $(p \leq 0.05)$. 


\section{Discussion}

\subsection{Crop Productivity and Profitability}

The weather condition at the study site were quite erratic during the study period. This reflects weather uncertainty in the Eastern IGP and hence climate-resilient management practices are crucial for sustained crop production with food and environmental security. During a 3-year study, the higher rice and wheat productivity with CSAPs (S4, S5 and S6), resulted in increased system productivity compared to farmers practices (S1, S2 and S3). The enhancement in the crop yield may be due to the combined effect of better crop and soil management by using minimum soil disturbance, crop residue retention/incorporation, laser land levelling, precision water and nutrient management. The findings of increased rice yield under CSAPs compared to puddled transplanted rice-PTR/FP are in agreement with the findings of other researchers $[2,37]$ in the region. These findings also support the earlier research based findings of the negative impact of puddled rice on the root growth of succeeding wheat crops due to soil compaction and poor soil aggregation [38]. As repeated tillage operations in PTR may have attributed to soil health deterioration due to compaction and increased bulk density and might result in poor yield of wheat [38]. Under changing scenario of climate risks research work carried out by Reference [8] in western IGP on climate smart agriculture practices layered with different portfolios of crop management practices offered maximum adaption to climatic risk and improvement in productivity and profitability of rice. In the present study in eastern IGP the superior yield responses of CSA practices were observed in wheat than in rice, while the system as a whole, the advantages of CSAPs were observed right from the first year and were continued over time (Table 6). In our study, the elimination of wet tillage (puddling) in rice had significant yield advantages on succeeding wheat crops, probably due to superior germination and extended rooting growth of wheat due to better soil physical properties. Consistent with the findings of our study, Reference [38] also reported higher yield of wheat by the eliminating puddling in the rice under rice-wheat system [39]. Other advantages of the adoption of component technologies of climate smart agriculture practices (like zero tillage with residue retention) minimized the yield penalty due to terminal heat stress in wheat as compared to conventional tillage [2]. Improvement in RW system productivity by the adopting of CSAPs might be due to the adoption of right crop management practices, proper land levelling $[4,39]$, selection of superior cultivar and suitable crop establishment method [15,40], precise management of water and better availability of nutrients [41].

Higher crop yields and lower production cost in CSAPs resulted into higher profitability of both the crops (rice and wheat) and RW system as a whole (Table 6). In our 3-year study; RW production system under CSAPs (S4, S5 and S6) incurred 1235-1265 USD ha ${ }^{-1}$ year $^{-1}$, whereas farmers practices (S1, S2 and S3) incurred 1275-1459 USD ha ${ }^{-1}$ year $^{-1}$ (Table 6). These lower production costs under CSAPs (S4, S5 and S6) were mainly due to non-requirement of preparatory tillage unlike CT, where 4-5 preparatory tillage operations were performed before transplanting of rice and seeding of wheat $[2,8]$. In RW cropping system, tillage and crop establishment methods are the major contributor to the total crop production costs [37]. A study conducted by Saharawat et al. [42] reported lower inputs requirement reduced the input costs to a great extent in direct seeded rice compared to transplanted rice. Higher net returns of RW system in CSAPs with S5 and S6 by 306-388 US\$ ha ${ }^{-1}$ year $^{-1}$ (3-year mean basis) than net returns of farmers practices (1278 USD ha ${ }^{-1}$ year ${ }^{-1}$; 3 -year mean the basis of S1, S2 and S3) (Table 6), Higher net returns were associated with CSAPs followed by improved FP due to lower cost of cultivation incurred in tillage operations, crop establishment, irrigation cost and higher crop yields (Table 6). Avoiding tillage, puddling and manual transplanting in rice and adoption of zero-till DSR reduced tillage and establishment cost (S3 to S6). Lesser water and labor requirement reduced the input costs to a great extent in DSR [40,42] compared to transplanted rice (TPR). Similarly, in wheat adoption of zero tillage using happy seeder (S4 to S6) reduced tillage cost by $70-80 \%$ compared to conventional tillage $[8,40]$. Higher crop yields and lower production cost in CSAPs resulted into higher profitability of RW system. 
Owing to lesser costs of crop production and superior yields under CSA based indicators (tillage, crop establishment, residue, nutrient and water management) gave higher net returns compared with conventional farmers' practice in the RW system $[2,15,40]$ and in the maize-based cropping systems [43].

\subsection{Water and Energy Use Efficiency}

The results of our 3-year study explicitly indicate that the climate smart agriculture practices (mean of S4, S5 and S6) in RW system utilized 21.4\%-35.4\% less irrigation water compared to farmers practices (mean of S1, S2 and S3). Under climate smart agriculture scenarios, like short-term weather forecasts [44], avoiding of puddling and retention of the crop residues on soil surface $[15,40]$ could reduce the average water requirement by $25 \%$ to $30 \%$ in the RW system. This may be due to less irrigation water requirement in climate smart agriculture practices layered with zero tillage, DSR, precise land levelling [13] and retention of crop residues on the soil surface. Application of less irrigation water for crop production in CSAPs due to lower supply requirement of irrigation water in CSA based component technologies that is, furrows plating [26,45]. In all the 3-years of study irrigation water productivity (WPI) of RW system was significantly higher with CSAPs $\left(2.1-2.5 \mathrm{~kg} \mathrm{~m}^{-3}\right.$ ) compared to farmers practices $\left(1.41-1.58 \mathrm{~kg} \mathrm{~m}^{-3}\right)$. Further, the retention of the residue of the surface in the component technology of CSAPs helped in reducing the losses through evaporation and hence conserves the soil moisture. More soil moisture in the seed-zone not only gave superior crop growth but also augmented crop IWP $[26,43,46,47]$. In RW cropping system, tillage, labor, irrigation and fertilizer use are mainly associated with energy inputs [48]. The present study analyzed the effects of CSA practices on energy consumption, net energy output, energy productivity and energy use efficiency in the RW system. The adoption of the CSA practices (mean of S4, S5 and S6) resulted in the enhancement of RW system 3-year energy input $\left(44-47 \times 10^{3} \mathrm{MJ} \mathrm{ha}^{-1}\right)$, energy outputs $\left(341-355 \times 10^{3} \mathrm{MJ} \mathrm{ha}^{-1}\right)$, energy productivity $\left(0.24-0.26 \mathrm{~kg} \mathrm{MJ}^{-1}\right)$ and energy use efficiency $\left(7.6-7.9 \mathrm{MJ} \mathrm{MJ}^{-1}\right)$ compared to FP, which showed the higher energy buildup capacity in CSAPs due to a better environment for crop growth in terms of higher nutrient availability, better root growth and modulation of microclimatic conditions with better water retention. Similar to the current study, Reference [8] also reported higher energy productivity and energy use efficiency under climate smart agriculture portfolios in the RW system. This may be due to lower energy input and higher energy output under CSAPs compared to FPs.

\subsection{Greenhouse Gases Emission and Mitigation Potential}

CSA practices, in addition to increasing the crop yields, profitability and water and energy use efficiency, have an impact on seasonal and annual greenhouse gases fluxes affecting climate change mitigation. The significant effect of CSAPs on seasonal and annual GHGs fluxes are most likely due to an interactive effect of soil management practices (tillage) on the soil physical structure, its biochemical characteristics and C [49]. At present, there is a scarcity of evidence on the impact of component technologies of CSAPs like zero tillage or other aspects of CA on GHGs emissions in the Indo-Gangetic Plains region in general and resource fragile Eastern IGP in particular. However, the issue is critical for determining the potential these component technologies of CSAPs to climate change mitigation as even a small increase in GHGs emission will offset a gain in soil organic carbon [50]. For example, 1 kilogram additionally emitted $\mathrm{N}_{2} \mathrm{O}$ from 1-hectare land will offset $0.13 \mathrm{MgCha}^{-1}$ sequestered. The data of the present study indicated that cumulative GHGs emissions in terms of $\mathrm{CO}_{2}$-equivalent (GWP) was $\sim 44 \%$ higher in the conventional tillage-based practices (FPs) than in CSAPs (Figure 3). The number of soil and environmental factors influence GHGs emission and are controlled by a variety of management practices such as type of fertilizers [51,52], fertilizer application method and time [53], crop type [51,54], irrigation pattern [55] and tillage practice [56]. In traditional tillage operations, different farming operations with the use of machineries having more diesel consumption that is, from sowing to harvesting, have considerable $\mathrm{CO}_{2}$ emission and also due to tillage operations soil get disturbed and emitted more $\mathrm{CO}_{2}$ in CT compared to ZT based productions. Similarly, Reference [57] 
reported 10 times higher GWP per unit of wheat yield in CT-based production system $\left(\sim 400 \mathrm{~kg} \mathrm{CO}_{2}\right.$-eq $\mathrm{Mg}^{-1}$ wheat yield) compared to ZT ( $\sim 35 \mathrm{~kg} \mathrm{CO}_{2}$-eq $\mathrm{Mg}^{-1}$ wheat yield). The cost beneficial mitigation options in Indian agriculture can be obtained up to $80 \%$ of the total technical mitigation potential (67.5 out of $85.5 \mathrm{Mt} \mathrm{CO}_{2}$ eq. year ${ }^{-1}$ ) [11]. While working in north-western IGP, Reference [8] reported $44 \%$ to $47 \%$ higher GWP under CT-based farmers' practices compared to ZT-based CSA practices. In contrast to the findings of the present study a number of researchers have reported superior annual GHGs emissions in NT than in CT plots [58-60], mainly from lowland rice crops.

\section{Conclusions}

Most of the earlier studies in IGP had focused on single cost-saving technology like zero tillage in wheat production systems and hence the possible payback from the combination of improved technologies has not been recognized. Therefore, the evaluation of system based holistic management strategy is essential to address the existing multifaceted challenges in RW system of Eastern IGP. Hence, the findings of the current study enriched the existing science-based knowledge regarding different aspects like energy use efficiency, water productivity, farm profitability and environment footprints of contrasting crop management scenarios in the RW system of Eastern IGP. Our results revealed that combinations of portfolios of best management practices over to existing farmers' practice improved crop yield and farm profitability with less consumption of irrigation water and environmental footprints in RW system. The adoption of CSAPs in the RW system became more profitable $(15 \%-20 \%)$ and adapted to erratic climate risks (save $25 \%$ to $29 \%$ irrigation water and reduced $44 \%$ GWP) than to traditional FP practices in this fragmented resource-poor and small farm holding dominated agro-ecology of India. Therefore, the adoption of CSAPs in rice-wheat rotation of Eastern IGP can significantly contribute to reducing agriculture's environmental footprints while improving productivity \& profitability (ensuring food security), resource use efficiency and sustaining natural resources under the emerging threat of climate change.

In aspects of carbon and energy efficiency the scope of CSAPs has immense significance, as it has the potential to replace a part of non-renewable energy and then farming will be more dependent on renewable sources. Therefore, in future, the synergistic combinations of the more diverse crop management practices suitable for particular crop and cropping systems and agro-ecology must be explored to achieve the SDGs.

\section{Future Perspective}

On the basis of the present study and the scientific evidence available, climate-smart agriculture (CSA) practices are constantly praised for increasing productivity, profitability, soil and environment quality while mitigation of climate changes. The multi-benefits are directly related to ecological and economical upliftment of farmer community. In a bid to heighten the farmer's awareness of the soil and environmental and nutritional benefits of climate smart agriculture in RW system, as part of sustainable food production for achieving food, nutrition and environmental security. To envisage the importance of CSA which are equally good for Indian's farming, their sustainability should be given priority. It is also well understood and proved by the researchers globally that CSA has the ability to improve the sustainability of RW system, by boosting, productivity, soil fertility and reducing dependence on external nutrients (millions of tons globally). Additionally, the importance of CSA in the RW system has also been explained in the text.

The vagaries of unforeseen negative factors of productivity need to be tackled smartly and cleverly. There are a few lines of research milestones that can help in augmenting crops, soil and environmental benefits via CSA. Some of them are:

> CSA in new niches-Popularizing CSA in RW system, which has approximately 14.3 million hectare area in Indo-Gangetic Plains (IGP), spread over four Asian countries- Pakistan, India, Nepal and Bangladesh. This large area of RW system offers huge potential and scope to expand CSA, thereby improving crop, soil, environmental and nutritional health. By adoption of zero 
tillage and crop residue directly helps in adding more SOC and releasing external nutrient input dependence.

$>$ Portfolios of CSA-The development of a portfolio of climate-smart agriculture practices could tackle the future problems of climate change and speedy depletion of the natural resource base.

$>$ Proper mechanization, capacity building of farmers through training and strong policy support needed for upscaling and adoption of CSAPs. This helps farmers to shift from conventional low profit and environment hazardous practices to beneficial CSAPs.

Author Contributions: The authors have undertaken this research for multiple years across the eastern IGP and all have contributed to this manuscript. D.B., R.K.J. conducted the research, D.B., C.M.P., S.K.K., K.K. analyzed the results and drafted the paper \& contributed to editing, M.L.J. conceptualized the research, funding acquisition and editing of manuscript. All authors have read and agreed to the published version of the manuscript.

Funding: This research was funded by CGIAR Research Programs on Climate Change, Agriculture and Food Security (CCAFS), Wheat Agri-Food Systems (WHEAT) and Indian Council of Agricultural Research (ICAR-DARE-W3).

Acknowledgments: The authors acknowledge to CGIAR Research Programs (CRPs) on Climate Change, Agriculture and Food Security (CCAFS), Wheat Agri-Food Systems (WHEAT) and Indian Council of Agricultural Research (ICAR) for financial support and support to conduct this research. The CGIAR Fund Council, Australia (ACIAR), Irish Aid, European Union, International Fund for Agricultural Development (IFAD), Netherlands, New Zealand, Switzerland, UK, USAID and Thailand is also acknowledged for funding.

Conflicts of Interest: The authors declare no conflict of interest.

\section{References}

1. Gupta, R.; Seth, A. A review of resource conserving technologies for sustainable management of the rice-wheat cropping systems of the Indo-Gangetic Plains (IGP). Crop. Protect 2007, 26, 436-447. [CrossRef]

2. Jat, R.K.; Sapkota, T.B.; Singh, R.G.; Jat, M.L.; Kumar, M.; Gupta, R.K. Seven years of conservation agriculture in a rice-wheat rotation of Eastern Gangetic Plains of South Asia: Yield trends and economic profitability. Field Crops Res. 2014, 164, 199-210. [CrossRef]

3. Saharawat, Y.S.; Singh, B.; Malik, R.K.; Ladha, J.K.; Gathala, M.; Jat, M.L.; Kumar, V. Evaluation of alternative tillage and crop establishment methods in a ricewheat rotation in North Western IGP. Field Crops Res. 2010, 116, 260-267. [CrossRef]

4. Humphreys, E.; Kukal, S.S.; Christen, E.W.; Hira, G.S.; Balwinder-Singh, S.-Y.; Sharma, R.K. Halting the groundwater decline in north-west India-Which crop technologies will be winners? Adv. Agron. 2010, 109, 155-217.

5. Kakraliya, S.K.; Kumar, S.; Kakraliya, S.S.; Choudhary, K.K.; Singh, L.K. Remedial options for the sustainability of rice-wheat cropping system. J. Pharm. Phys. 2018, 7, 163-171.

6. Jat, M.L.; Dagar, J.C.; Sapkota, T.B.; Singh, Y.; Govaerts, B.; Ridaura, S.L.; Saharawat, Y.S.; Sharma, R.K.; Tetarwal, J.P.; Jat, R.K.; et al. Climate change and agriculture: Adaptation strategies and mitigation opportunities for food security in South Asia and Latin America. Adv. Agron. 2016, 137, 127-236.

7. Jat, R.K.; Singh, R.G.; Kumar, M.; Jat, M.L.; Parihar, C.M.; Bijarniya, D.; Sutaliya, J.M.; Jat, M.K.; Parihar, M.D.; Kakraliya, S.K.; et al. Ten years of conservation agriculture in a rice-maize rotation of Eastern Gangetic Plains of India: Yield trends, water productivity and economic profitability. Field Crops Res. 2018, 232, 1-10. [CrossRef]

8. Kakraliya, S.; Jat, H.; Singh, I.; Sapkota, T.; Singh, L.; Sutaliya, J.; Sharma, P.; Jat, R.; Lopez-Ridaura, S.; Jat, M. Performance of portfolios of climate smart agriculture practices in a rice-wheat system of western Indo-Gangetic plains. Agric. Water Manag. 2018, 202, 122-133. [CrossRef]

9. Kumar, V.; Ladha, J.K. Direct seeding of rice: Recent developments and future research needs. Adv. Agron. 2011, 111, 299-360.

10. Aryal, J.P.; Jat, M.L.; Sapkota, T.B.; Kassie, A.; Rahut, D.B.; Maharjan, S. Adoption of multiple climate-smart agricultural practices in the Gangetic plains of Bihar, India. Int. J. Clim. Chang. Struct. 2018, 10, 407-427. [CrossRef] 
11. Sapkota, T.B.; Vetter, S.H.; Jat, M.L.; Sirohi, S.; Shirsath, P.B.; Singh, R.; Jat, H.S.; Smith, P.; Hillier, J.; Stirling, C.M. Cost-effective opportunities for climate change mitigation in Indian agriculture. Sci. Total Environ. 2018, 655, 1342-1354. [CrossRef] [PubMed]

12. FAO. Climate-smart agriculture, policies, practices and financing for food security, sdaptation and mitigation. In Proceedings of the Hague Conference on Agriculture, Food Security and Climate Change, Rome, Italy, 31 October-5 November 2010.

13. Jat, M.L.; Gupta, R.; Saharawat, Y.S.; Khosla, R. Layering precision land levelling and furrow irrigated raised bed planting: Productivity and input use efficiency of irrigated bread wheat in Indo-Gangetic Plains. Am. J. Plant. Sci. 2011, 2, 578-588. [CrossRef]

14. Jat, R.K.; Singh, P.; Jat, M.L.; Dia, M.; Sidhu, H.S.; Jat, S.L.; Bijarniya, D.; Jat, H.S.; Parihar, C.M.; Kumar, U.; et al. Heat stress and yield stability of wheat genotypes under different sowing dates across agro-ecosystems in India. Field Crops Res. 2018, 218, 33-50. [CrossRef]

15. Kumar, V.; Jat, H.S.; Sharma, P.C.; Gathala, M.K.; Malik, R.K.; Kamboj, B.R.; Yadav, A.K.; Ladha, J.K.; Raman, A.; Sharma, D.K.; et al. Can productivity and profitability be enhanced in intensively managed cereal systems while reducing the environmental footprint of production? Assessing sustainable intensification options in the breadbasket of India. Agric. Ecosyst. Environ. 2018, 252, 132-147. [CrossRef] [PubMed]

16. Chopra, S.L.; Kanwar, J.S. Analytical Agriculture Chemistry, 4th ed.; Kalyani Publishers: New Delhi, India, 1991; p. 301.

17. Richards, L.A. Diagnosis and Improvement in Saline, Alkali Soils; Handbook No. 60; USDA: Washington, DC, USA, 1954.

18. Walkley, A.; Black, C.A. An examination of the method for determination of soil organic matter and proposed medication at the chromic acid titration method. Soil Sci. 1934, 37, 29-38. [CrossRef]

19. Subbiah, B.V.; Asija, G.L. A rapid procedure for the estimation of available nitrogen in soils. Curr. Sci. 1956, 25, 259-260.

20. Olsen, S.; Cole, C.V.; Walanafle, F.S.; Dean, L.A. Estimation of Available Phosphorus in Soil Extraction with Sodium Bicarbonate; Circular No. 939; USDA: Washington, DC, USA, 1954.

21. Jackson, M.L. Soil Chemical Analysis, 2nd ed.; Prentice Hall of India Pvt. Ltd.: New Delhi, India, $1973 ;$ p. 498.

22. Singh, B.; Sharma, R.K.; Kaur, J.; Jat, M.L.; Martin, K.L.; Singh, Y.; Singh, V.; Chandna, P.; Choudhary, O.P.; Gupta, R.K.; et al. Assessment of the nitrogen management strategy using an optical sensor for irrigated wheat. Agron. Sustain. Dev. 2011, 31, 589-603. [CrossRef]

23. Singh, B.; Singh, V.; Purba, J.; Sharma, R.K.; Jat, M.L.; Singh, Y.; Thind, H.S.; Gupta, R.K.; Chaudhary, O.P.; Chandna, P.; et al. Site-specific fertilizer nitrogen management in irrigated transplanted rice (Oryza sativa) using an optical sensor. Precis. Agric. 2015, 16, 455-745. [CrossRef]

24. Pampolino, M.F.; Witt, C.; Pasuquin, J.M.; Johnston, A.; Fisher, M.J. Development approach and evaluation of the Nutrient Expert software for nutrientt management in cereal crops. Comput. Electron. Agric. 2012, 88, 103-110. [CrossRef]

25. Parihar, C.M.; Jat, S.L.; Singh, A.K.; Ghosh, A.; Rathore, N.S.; Kumar, B.; Pradhan, S.; Majumdar, K.; Satyanarayana, T.; Jat, M.L.; et al. Effects of precision conservation agriculture in a maize-wheat-mungbean rotation on crop yield, water use and radiation conversion under a semiarid agro-ecosystem. Agric. Water Manag. 2017, 192, 306-319. [CrossRef]

26. Parihar, C.M.; Jat, S.L.; Singh, A.K.; Majumdar, K.; Jat, M.L.; Saharawat, Y.S.; Pradhan, S.; Kuri, B.R. Bio-energy, water-use efficiency and economics of maize-wheat mungbean system under precision-conservation agriculture in semi-arid agro-ecosystem. Energy 2017, 119, 245-256. [CrossRef]

27. Parihar, C.M.; Jat, S.L.; Singh, A.K.; Kumar, B.; Rathore, N.S.; Jat, M.L.; Saharawat, Y.S.; Kuri, B.R. Energy auditing of long-term conservation agriculture based irrigated intensive maize systems in semi-arid tropics of India. Energy 2018, 42, 289-302. [CrossRef]

28. Feliciano, D.; Nayak, D.; Vetter, S.; Hillier, J. CCAFS Mitigation Option Tool. 2015. Available online: http://www.ccafs.cigar.org (accessed on 26 April 2019).

29. Bouwman, A.F.; Boumans, L.J.M.; Batjes, N.H. Modeling global annual $\mathrm{N}_{2} \mathrm{O}$ and $\mathrm{NO}$ emissions from fertilized fields. Glob. Biogeochem. Cycles 2002, 16, 281-289. [CrossRef]

30. FAO/IFA. Global Estimates of Gaseous Emissions of $\mathrm{NH3}, \mathrm{NO}$ and $\mathrm{N}_{2} \mathrm{O}$ from Agricultural Land; Food and Agriculture Organization of the United Nations (FAO) and International Fertilizer Industry Association (IFA): Rome, Italy, 2001. 
31. Ogle, S.M.; Breidt, F.J.; Paustian, K. Agricultural management impacts on soil organic carbon storage under moist and dry climatic conditions of temperate and tropical regions. Biogeochemistry 2005, 72, 87-121. [CrossRef]

32. Smith, P.; Powlson, D.; Glendining, M.; Smith, J.O. Potential for carbon sequestration in European soils: Preliminary estimates for five scenarios using results from long-term experiments. Glob. Chang. Biol. 1997, 3, 67-79. [CrossRef]

33. IPCC. IPCC Guidelines for National Greenhouse Gas Inventories; The National Greenhouse Gas Inventories, Programme; Eggleston, H.S., Ed.; Institute for Global Environmental Strategies: Hayama, Japan, 2006.

34. IPCC. Climate Change 2013: The Physical Science Basis in Contribution of Working Group I to the Fifth Assessment Report of the Intergovernmental Panel on Climate Change; Stocker, T.F., Ed.; IPCC: New York, NY, USA, 2013; pp. 710-716.

35. Gomez, K.A.; Gomez, A.A. Statistical Procedures for Agricultural Research; John Wiley \& Sons: New York, NY, USA, 1984.

36. SAS Institute. SAS/STAT User's Guide. Version 8-1; SAS Inst.: Cary, NC, USA, 2001.

37. Gathala, M.K.; Ladha, J.K.; Saharawat, Y.S.; Kumar, V.; Kumar, V.; Sharma, P.K. Effect of tillage and crop establishment methods on physical properties of a medium textured soil under a seven-year rice-wheat rotation. Soil Sci. Soc. Am. J. 2011, 75, 1851-1862. [CrossRef]

38. Kakraliya, S.K.; Singh, I.; Dadarwal, R.S.; Singh, L.K.; Jat, R.D.; Jat, H.S.; Jat, M.L. Impact of climate-smart agricultural practices on growth and crop yields of rice (Oryza sativa)-wheat (Triticum aestivum) system in north-western Indo-Gangetic Plains. Indian J. Agric. Sci. 2018, 88, 1543-1551.

39. Gathala, M.K.; Ladha, J.K.; Saharawat, Y.S.; Sharma, P.K.; Sharma, S.; Pathak, H. Tillage and crop establishment affects sustainability of South Asian rice-wheat system. Agron. J. 2011, 103, 961. [CrossRef]

40. Gathala, M.K.; Kumar, V.; Sharma, P.C.; Saharawat, Y.S.; Jat, H.S.; Singh, M.; Kumar, A.; Jat, M.L.; Humphreys, E.; Sharma, D.K.; et al. Optimizing intensive cereal-based cropping systems addressing current and future drivers of agricultural change in the North-western Indo-Gangetic Plains of India. Agric. Ecosyst. Environ. 2014, 187, 33-46. [CrossRef]

41. Choudhary, K.M.; Jat, H.S.; Nandal, D.P.; Bishnoi, D.K.; Sutaliya, J.M.; Choudhary, M.; Yadvinder-Singh Sharma, P.C.; Jat, M.L. Evaluating alternatives to rice-wheat system in western Indo-Gangetic Plains: Crop yields, water productivity and economic profitability. Field Crops Res. 2018, 218, 1-10. [CrossRef]

42. Saharawat, Y.S.; Ladha, J.K.; Pathak, H.; Gathala, M.; Chaudhary, N.; Jat, M.L. Simulation of resource-conserving technologies on productivity, income and greenhouse gas GHG emission in rice-wheat system. J. Soil Sci. Environ. Manag. 2012, 3, 9-22.

43. Parihar, C.M.; Jat, S.L.; Singh, A.K.; Kumar, B.; Yadvinder-Singh, P.S.; Pooniya, V.; Dhauja, A.; Chaudhary, V.; Jat, M.L.; Jat, R.K.; et al. Conservation agriculture in irrigated intensive maize-based systems of North-Western India: Effects on crop yields, water productivity and economic profitability. Field Crops Res. 2016, 193, 104-116. [CrossRef]

44. Mishra, A.; Siderius, C.; Aberson, K.; Ploeg, M.; Froebrich, J. Short-term rainfall forecasts as a soft adaptation to climate change in irrigation management in North-East India. Agric. Water Manag. 2013, 127, 97-106. [CrossRef]

45. Aggarwal, P.; Goswami, B. Bed planting system for increasing water use efficiency of wheat grown on Inceptisol. Indian J. Agric. Sci. 2003, 73, 422-425.

46. Sidhu, H.S.; Singh, M.; Singh, Y.; Blackwell, J.; Lohan, S.K.; Humphreys, E.; Jat, M.L.; Singh, V.; Singh, S. Development and evaluation of the turbo happy seeder for sowing wheat into heavy rice residues in NW India. Field Crops Res. 2015, 184, 201-212. [CrossRef]

47. Sharma, P.C.; Jat, H.S.; Kumar, V.; Gathala, M.K.; Datta, A.; Yaduvanshi, N.P.S.; Choudhary, M.; Sharma, S.; Singh, L.K.; Saharawat, Y.; et al. Sustainable Intensification Opportunities under Current and Future Cereal Systems of North-West India, Technical Bulletin: CSSRI/Karnal/2015/4; Central Soil Salinity Research Institute: Karnal, India, 2015; p. 46. [CrossRef]

48. Aravindakshan, S.; Rossi, F.J.; Krupnik, T.J. What does benchmarking of wheat farmers practicing conservation tillage in the eastern Indo-Gangetic Plains tell us about energy use efficiency? An application of slack-based data envelopment analysis. Energy 2015, 90, 483-493. [CrossRef] 
49. Bayer, C.; Gomes, J.; Zanatta, J.A.; Vieira, F.C.B.; Piccolo, M.; de Cássia Dieckow, J.; Six, J. Soil nitrous oxide emissions as affected by long-term tillage, cropping systems and nitrogen fertilization in Southern Brazil. Soil Till Res. 2015, 146, 213-222. [CrossRef]

50. Grandy, A.S.; Loecke, T.D.; Parr, S.; Robertson, G.P. Long-term trends in nitrous oxide emissions, soil nitrogen and crop yields of till and no-till cropping systems. J. Environ. Sci. 2006, 35, 1487-1495. [CrossRef]

51. Albanito, F.; Lebender, U.; Cornulier, T.; Sapkota, T.B.; Brentrup, F.; Stirling, C.; Hillier, J. Direct nitrous oxide emissions from tropical and sub-tropical agricultural systems-A review and modelling of emission factors. Sci. Rep. 2017, 7, 1-12. [CrossRef]

52. Zhou, M.; Zhu, B.; Wang, S.; Zhu, X.; Vereecken, H.; Brüggemann, N. Stimulation of $\mathrm{N}_{2} \mathrm{O}$ emission by manure application to agricultural soils may largely offset carbon benefits: A global meta-analysis. Glob. Chang. Biol. 2017, 23, 4068-4083. [CrossRef]

53. Tenuta, M.; Gao, X.; Flaten, D.N.; Amiro, B.D. Lower Nitrous Oxide Emissions from Anhydrous Ammonia Application Prior to Soil Freezing in Late Fall Than Spring Pre-Plant Application. J. Environ. Qual. 2015, 45, 1133-1143. [CrossRef] [PubMed]

54. Gerber, J.S.; Carlson, K.M.; Makowski, D.; Mueller, N.D.; Garcia de Cortazar-Atauri, I.; Havlík, P.; Herrero, M.; Launay, M.; O'Connell, C.S.; Smith, P.; et al. Spatially explicit estimates of $\mathrm{N}_{2} \mathrm{O}$ emissions from croplands suggest climate mitigation opportunities from improved fertilizer management. Glob. Chang. Biol. 2016, 22, 3383-3394. [CrossRef] [PubMed]

55. Han, B.; Ye, X.; Li, W.; Zhang, X.; Zhang, Y.; Lin, X.; Zou, H. The effects of different irrigation regimes on nitrous oxide emissions and influencing factors in greenhouse tomato fields. J. Soils Sediments 2017, 17, 2457-2468. [CrossRef]

56. Sapkota, T.B.; Jat, M.L.; Shankar, V.; Singh, L.K.; Rai, M.; Grewal, M.S.; Stirling, C.M. Tillage residue and nitrogen management effects on methane and nitrous oxide emission from rice-wheat system of Indian Northwest Indo-Gangetic Plains. J. Integr. Environ. Sci. 2015, 12 (Suppl. 1), 31-46. [CrossRef]

57. Sapkota, T.B.; Shankar, V.; Rai, M.; Jat, M.L.; Stirling, C.M.; Singh, L.K.; Jat, H.S.; Grewal, M.S. Reducing global warming potential through sustainable intensification of basmati rice-wheat systems in India. Sustainability 2017, 9, 1044. [CrossRef]

58. Tan, I.Y.S.; van Es, H.M.; Duxbury, J.M.; Melkonian, J.J.; Schindelbeck, R.R.; Geohring, L.D.; Hively, W.D.; Moebius, B.N. Single-event nitrous oxide losses under maize production as affected by soil type tillage, rotation and fertilization. Soil Till Res. 2009, 102, 19-26. [CrossRef]

59. Regina, K.; Alakukku, L. Greenhouse gas fluxes in varying soils types under conventional and no-tillage practices. Soil Till Res. 2010, 109, 144-152. [CrossRef]

60. Gupta, D.K.; Bhatia, A.; Kumar, A.; Chakrabarti, B.; Jain, N.; Pathak, H. Global warming potential of rice (Oryza sativa)-wheat (Triticum aestivum) cropping system of the Indo-Gangetic Plains. Indian J. Agric. Sci. 2015, 85, 807-816.

Publisher's Note: MDPI stays neutral with regard to jurisdictional claims in published maps and institutional affiliations.

(C) 2020 by the authors. Licensee MDPI, Basel, Switzerland. This article is an open access article distributed under the terms and conditions of the Creative Commons Attribution (CC BY) license (http://creativecommons.org/licenses/by/4.0/). 